\title{
Impact of Mitochondrial Genetic Variants in ND1, ND2, ND5, and ND6 Genes on Sperm Motility and Intracytoplasmic Sperm Injection (ICSI) Outcomes
}

\author{
Mohammad A. Al Smadi ${ }^{1}$ (D) Mohamad Eid Hammadeh ${ }^{1} \cdot$ Erich Solomayer $^{1} \cdot$ Osamah Batiha $^{2}$. \\ Mohammad M. Altalib ${ }^{3} \cdot$ Mohammad Y. Jahmani $^{1} \cdot$ Mohammad A. Shboul $^{4} \cdot$ Bassam Nusair $^{5} \cdot$ Houda Amor $^{1}$
}

Received: 28 September 2020 / Accepted: 29 December 2020 / Published online: 21 January 2021

(C) The Author(s) 2021

\begin{abstract}
Sperm mitochondrial dysfunction causes the generation of an insufficient amount of energy needed for sperm motility. This will affect sperm fertilization capacity, and thus, most asthenozoospermic men usually require assisted reproductive techniques. The etiology of asthenozoospermia remains largely unknown. The current study aimed to investigate the effect of mitochondrial genetic variants on sperm motility and intracytoplasmic sperm injection (ICSI) outcomes. A total of 150 couples from the ICSI cycle were enrolled in this study. One hundred five of the male partners were asthenozoospermic patients, and they were subdivided into three groups according to their percentage of sperm motility, while forty-five of the male partners were normozoospermic. Genetic variants were screened using direct Sanger's sequencing in four mitochondrial genes (nicotinamide adenine dinucleotide hydrogen (NADH) dehydrogenase 1 (ND1), NADH dehydrogenase 2 (ND2), NADH dehydrogenase 5 (ND5), and NADH dehydrogenase 6 (ND6)). We identified three significant variants: 13708G $>$ A (rs28359178) in ND5, 4216T $>C$ (rs1599988) in ND1, and a novel 12506T >A in ND5 with $P$ values $0.006,0.036$, and 0.013 , respectively. The medians of sperm motility, fertilization rate, embryo cleavage score, and embryo quality score were significantly different between men showing 4216T $>$ C, 12506T $>$ A, 13708G $>$ A and wild type, Mann-Whitney $P$ values for the differences in the medians were $<0.05$ in all of them. The results from this study suggest that $13708 \mathrm{G}>\mathrm{A}, 12506 \mathrm{~T}>\mathrm{A}$, and $4216 \mathrm{~T}>\mathrm{C}$ variants in sperm mitochondrial DNA negatively affect sperm motility and ICSI outcomes.
\end{abstract}

Keywords mtDNA $\cdot$ Asthenozoospermia $\cdot$ Sperm motility $\cdot$ Fertilization rate $\cdot$ Embryo cleavage score $\cdot$ Embryo quality score

\section{Introduction}

Genetic variants in mitochondrial genes are associated with many diseases [1]. Most of these diseases affect organs with

Mohammad A. Al Smadi

m_alsmadi@yahoo.com

1 Department of Obstetrics \& Gynecology, Reproductive Medicine Unit, Saarland University, Homburg, Germany

2 Department of Biotechnology \& Genetic Engineering, Jordan University of Science and Technology, Irbid, Jordan

3 Department of Statistics, Yarmouk University, Irbid, Jordan

4 Department of Medical Laboratory Sciences, Jordan University of Science and Technology, Irbid, Jordan

5 Reproductive Endocrinology and IVF Unit, King Hussein Medical Centre, Amman, Jordan high energy demand, such as the brain, the skeletal muscle, the eye, and the heart [2]. Because mitochondrial DNA (mtDNA) is not protected by histones or other DNA-binding proteins, it is more prone to DNA damage caused by excess levels of reactive oxygen species (ROS) and free radicals present in the matrix [3]. Furthermore, the mtDNA repair mechanism is less efficient compared to nuclear DNA repair [4]. Together, these factors increase the mutation rate in mtDNA, compared to nuclear DNA by 10-100 times [5].

Sperm depends on the mitochondrial oxidative phosphorylation (OxPhos) mechanism to produce the required energy for its motility [6]; therefore, mutated mtDNA leads to energy insufficiency, which causes a reduction in sperm motility [7]. In comparison to the oocyte, which has around 150,000 mtDNA copies, the spermatozoa have only around 100 mtDNA copies [8].

Sperms usually produce ROS in a natural physiological process, and ROS at low levels are necessary for sperm 
function, as they play a significant role in sperm maturation, acrosome reaction, and sperm-oocyte fusion [9]. Excess levels of ROS have a damaging effect, leading to nuclear DNA strand breaks [10]. Leukocytes in the semen produce ROS one thousand times more than sperms, where such a situation is common during urinary tract infection (UTI) [11]. Mitochondrial dysfunction, caused by the production of high levels of ROS from complex I, has been shown to cause lipid peroxidative damage to the sperm midpiece and to result in a reduction in the sperm motility [12].

Seminal plasma is the major source of antioxidants that protect sperm cells against oxidative damages [13]. A significant decrease in the reduced to oxidized glutathione ratio and total glutathione levels in seminal plasma among groups of males with varicocele and idiopathic infertility has been reported [14].

It has been thought for a long time that mtDNA was inherited restrictedly from the mother, but a recent study has challenged this idea and provided evidence of additional paternal mtDNA transmission from fathers to offspring [15], where paternal mtDNA is governed by a quasi-Mendelian inheritance [16]. Furthermore, during intracytoplasmic sperm injection (ICSI) the whole sperm is injected into the cytoplasm of the oocyte, interestingly, the mtDNA is occasionally preserved, so that the offspring may indeed share their father's mitochondrial DNA [17].

Sperm motility has been shown to be affected by variations in the mitochondrial genome. Two single nucleotide polymorphisms (SNPs) in ATPase6 and ND4 mitochondrial genes at 9055 and 11719 loci, respectively, were found to be associated with asthenozoospermia [18]. Furthermore, a recent study has found a missense variant $(11696 \mathrm{G}>\mathrm{A})$ in the MT-ND4 gene to be associated with reduced sperm motility and causing the replacement of valine residue at position 313 with isoleucine, leading to a change in the secondary structure of the protein [19].

Several studies have shown connections between mitochondrial mutations, sperm motility, fertilization rate, and pregnancy completion. A study found that the fertilization rate had a strong positive correlation with sperm motility [20]. Moreover, a point mutation in the ND1 gene at locus 4216 has been associated with recurrent pregnancy loss [21]. On the other hand, another study found that embryo grading at day 3 can predict the pregnancy rate of the in vitro fertilization (IVF) cycle, where embryos with high-quality scores have a better chance of a successful embryo transfer compared to embryos with a low-quality score [22].

The aim of this study was to investigate the influence of genetic variations in four mitochondrial genes $(N D 1, N D 2$, $N D 5$, and ND6) on sperm motility and ICSI outcomes. This study is part of a larger project that aims to understand the role of mitochondrial genetic variants in infertility.

\section{Methods}

\section{Subjects}

From August 2018 to October 2019, samples were collected from 150 male partners, aged $<40$ years, of ICSI couples that attended Assisted Reproductive Techniques (ART) Department at Prince Rashid Bin AL Hassan Hospital (PRBH), Irbid, Jordan.

According to the World Health Organization (WHO) laboratory manual for semen analysis, the total motility (progressive motility (PR) and non-progressive motility (NP)) for a normal male should be above $40 \%$; otherwise, it will be considered to be asthenozoospermic. One hundred five of these samples were from asthenozoospermic men ( $\mathrm{PR}+\mathrm{NP}<40 \%)$ and were divided into three groups according to their percentage of sperm motility. Group 1 included patients with sperm motility from 0 to $5 \%$, group 2 included patients with sperm motility from 6 to $15 \%$, and group 3 included patients with sperm motility from 16 to $35 \%$. Forty-five samples of normozoospermic men with a high percentage of sperm motility between $50 \%$ and $75 \%$ were also collected as controls. The other semen parameters were within normal ranges (Table 1), Patients with varicocele, and alcoholic problems, as well as cigarette smokers and patients with genetic abnormalities, such as Klinefelter's syndrome, were excluded from this study. The study was approved by the Jordanian Royal Medical Services-Human Research Ethics Committee on 30/7/2018 with the project identification code (TF3/1/Ethics Committee/9126), and written consent from each couple was obtained.

Semen samples were obtained from all subjects by masturbation after 3 to 5 days of sexual restraint. The samples were incubated at $37{ }^{\circ} \mathrm{C}$ for $30 \mathrm{~min}(\mathrm{~min})$ to allow liquefaction. Then they were evaluated by a senior clinical embryologist according to WHO criteria (WHO, 2010).

\section{Semen Preparation for ICSI}

Semen samples were fractionated by Percoll media ( $45 \%$ and $90 \%$ gradient) through centrifugation at $1000 \mathrm{~g}$ for $22 \mathrm{~min}$.

Table 1 Semen parameters among groups

\begin{tabular}{lllll}
\hline & $\begin{array}{l}\text { Semen } \\
\text { volume } \\
(\mathrm{ml}), \\
\text { median } \pm \\
\text { SD }\end{array}$ & $\begin{array}{l}\text { Sperm } \\
\text { concentration } \\
\left(10^{6} \text { per } \mathrm{ml}\right), \\
\text { median } \pm \mathrm{SD}\end{array}$ & $\begin{array}{l}\text { Total } \\
\text { motility (PR } \\
+ \text { NP \%), } \\
\text { median } \pm \text { SD }\end{array}$ & $\begin{array}{l}\text { Morphologically } \\
\text { normal } \\
\text { spermatozoa }(\%), \\
\text { median } \pm \text { SD }\end{array}$ \\
\hline $\begin{array}{c}\text { Group } \\
1\end{array}$ & $2.63 \pm 1.18$ & $32.04 \pm 15.12$ & $0 \pm 2.57$ & $5.78 \pm 3.14$ \\
$\begin{array}{c}\text { Group } \\
2\end{array}$ & $3.1 \pm 2.16$ & $40.56 \pm 27.88$ & $9 \pm 3.40$ & $4.89 \pm 2.45$ \\
$\begin{array}{c}\text { Group } \\
3\end{array}$ & $2.89 \pm 1.43$ & $61.13 \pm 39.74$ & $20 \pm 6.99$ & $6.13 \pm 5.69$ \\
Control & $3.2 \pm 1.35$ & $73.16 \pm 52.21$ & $58 \pm 9.05$ & $8.82 \pm 7.03$ \\
\hline
\end{tabular}


Table 2 Primers list for PCR amplification and Sanger sequencing

\begin{tabular}{lll} 
Primer name & Sequence $\left(5^{\prime}-3^{\prime}\right)$ & $\begin{array}{l}\text { Product } \\
\text { length }\end{array}$ \\
\hline MT-ND1-F & CACCCACCCAAGAACAGGGT & 1155 \\
MT-ND1-R & TTCTCAGGGATGGGTTCGATTC & \\
MT-ND2-F & TCAGCTAAATAAGCTATCGGGC & 1200 \\
MT-ND2-R & GAGTGGGGTTTGCAGTCCT & \\
MT-ND5-F & CTGCTAACTCATGCCCCCAT & 2043 \\
MT-ND5-R & GGAGGATCCTATTGGTGCGG & \\
MT-ND6-F & CCTCTCTTTCTTCTTCCCACTCA & 622 \\
MT-ND6-R & CGATGGTTTTTCATATCATT & \\
& GGTCG & $*$ \\
ND5A & CTAAACGCTAATCCAAGCC & $*$ \\
ND5B $^{*}$ & CTATTACTCTCATCGCTACCTC & $*$
\end{tabular}

$\mathrm{ND}^{*} \mathrm{~A}^{*}$ and $\mathrm{ND}^{\mathrm{B}} \mathrm{B}^{*}$ are additional internal primers were designed for Sanger sequencing only
After that, the pellet was collected and washed twice with a sperm-washing medium. Supernatants were discarded, and then the pellet was gently layered with 4-(2-hydroxyethyl)1-piperazineethanesulfonic acid (HEPES) (21 mM, PH = 7.3 ) plus $0.5 \%$ human serum albumin (Sage, USA). After that, the sperm pellet was collected and placed in the $\mathrm{CO}_{2}$ incubator at $37^{\circ} \mathrm{C}$ for $1 \mathrm{~h}$, and later on the surface layer was aspired. Only sperm samples with $0 \%$ percentage of sperm motility were washed without this HEPES layering.

\section{The ICSI Technique}

The oocytes were denudated after $2 \mathrm{~h}$ of egg retrieval by both chemical and mechanical treatments. Chemical denudation was performed using a hyaluronidase enzyme, while the mechanical denudation was done by aspirating the oocytes through glass pipettes (with a 150-300 $\mu \mathrm{m}$ inner diameter)

Table 3 The mtDNA variants identified in the ND1 gene

\begin{tabular}{|c|c|c|c|c|c|c|}
\hline Serial Number & MtDNA variant & Amino Acid change & Frequency of variant in control & Frequency of variant in asthenozoospermia & G test & $P$ value \\
\hline 1 & $3316 \mathrm{G}>\mathrm{A}$ & Ala $>$ Thr & $0 / 45$ & $5 / 105$ & 3.64 & 0.056 \\
\hline 2 & $3348 \mathrm{~A}>\mathrm{G}$ & Leu>Leu & $2 / 45$ & $3 / 105$ & 0.234 & 0.629 \\
\hline 3 & $3480 \mathrm{~A}>\mathrm{G}$ & Lys $>$ Lys & $2 / 45$ & $6 / 105$ & 0.104 & 0.747 \\
\hline 4 & $3462 \mathrm{C}>\mathrm{T}$ & Ala $>$ Ala & $0 / 45$ & $3 / 105$ & 2.166 & 0.141 \\
\hline 5 & $3537 \mathrm{~A}>\mathrm{G}$ & Leu $>$ Leu & $0 / 45$ & $1 / 105$ & 0.716 & 0.397 \\
\hline 6 & $3594 \mathrm{C}>\mathrm{T}$ & Val $>$ Val & $1 / 45$ & $3 / 105$ & 0.051 & 0.822 \\
\hline 7 & $3720 A>G$ & Gln $>$ Gln & $0 / 45$ & $1 / 105$ & 0.716 & 0.397 \\
\hline 8 & $3741 \mathrm{C}>\mathrm{T}$ & Thr $>$ Thr & $0 / 45$ & $1 / 105$ & 0.716 & 0.397 \\
\hline 9 & $3826 \mathrm{~T}>\mathrm{C}$ & Leu $>$ Leu & $0 / 45$ & $1 / 105$ & 0.716 & 0.397 \\
\hline 10 & $3882 \mathrm{G}>\mathrm{A}$ & $\mathrm{Gln}>\mathrm{G} \ln$ & $0 / 45$ & $2 / 105$ & 1.438 & 0.23 \\
\hline 11 & $3921 \mathrm{C}>\mathrm{T}$ & Ser $>$ Ser & $0 / 45$ & $1 / 105$ & 0.716 & 0.397 \\
\hline 12 & $4086 \mathrm{C}>\mathrm{T}$ & Val>Val & $0 / 45$ & $1 / 105$ & 0.716 & 0.397 \\
\hline 13 & $4216 \mathrm{~T}>\mathrm{C}^{*}$ & Tyr $>$ His & $0 / 45$ & $10 / 105$ & 7.436 & $0.006^{*}$ \\
\hline 14 & $4017 \mathrm{C}>\mathrm{T}$ & Leu $>$ Leu & $0 / 45$ & $1 / 105$ & 0.716 & 0.397 \\
\hline 15 & $3705 \mathrm{G}>\mathrm{A}$ & Leu $>$ Leu & $0 / 45$ & $3 / 105$ & 2.166 & 0.141 \\
\hline 16 & $3505 \mathrm{~A}>\mathrm{G}$ & Thr $>$ Ala & $0 / 45$ & $1 / 105$ & 0.716 & 0.397 \\
\hline 17 & $4104 \mathrm{~A}>\mathrm{G}$ & Leu $>$ Leu & $1 / 45$ & $4 / 105$ & 0.266 & 0.606 \\
\hline 18 & $3847 \mathrm{~T}>\mathrm{C}$ & Leu $>$ Leu & $0 / 45$ & $1 / 105$ & 0.716 & 0.397 \\
\hline 19 & $3834 \mathrm{G}>\mathrm{A}$ & Leu $>$ Leu & $1 / 45$ & $1 / 105$ & 0.354 & 0.552 \\
\hline 20 & $3843 \mathrm{~A}>\mathrm{G}$ & $\operatorname{Tr} p>\operatorname{Tr} p$ & $0 / 45$ & $1 / 105$ & 0.716 & 0.397 \\
\hline 21 & $3819 \mathrm{C}>\mathrm{T}$ & His $>$ His & $0 / 45$ & $1 / 105$ & 0.716 & 0.397 \\
\hline 22 & $3335 \mathrm{~T}>\mathrm{C}$ & Ile $>$ Thr & $0 / 45$ & $1 / 105$ & 0.716 & 0.397 \\
\hline 23 & $3396 \mathrm{~T}>\mathrm{C}$ & Tyr $>$ Tyr & $0 / 45$ & $1 / 105$ & 0.716 & 0.397 \\
\hline 24 & $3483 \mathrm{G}>\mathrm{A}$ & Glu $>$ Glu & $0 / 45$ & $1 / 105$ & 0.716 & 0.397 \\
\hline 25 & $3666 \mathrm{G}>\mathrm{A}$ & Gly $>$ Gly & $1 / 45$ & $0 / 105$ & 2.424 & 0.12 \\
\hline 26 & $3915 \mathrm{G}>\mathrm{A}$ & Gly $>$ Gly & $0 / 45$ & $1 / 105$ & 0.716 & 0.397 \\
\hline 27 & $3992 \mathrm{C}>\mathrm{T}$ & Thr> Met & $0 / 45$ & $1 / 105$ & 0.716 & 0.397 \\
\hline 28 & $3593 \mathrm{~T}>\mathrm{C}$ & Val $>$ Ala & $0 / 45$ & $1 / 105$ & 0.716 & 0.397 \\
\hline 29 & $3513 \mathrm{C}>\mathrm{T}$ & Thr $>$ Thr & $1 / 45$ & $1 / 105$ & 0.354 & 0.552 \\
\hline
\end{tabular}

${ }^{*}$ Statistically significant difference, $P$ value $<0.05$ 
in HEPES, covered with oil (Vitrolife, Sweden). After $3 \mathrm{~h}$ in the $\mathrm{CO}_{2}$ incubator at $37^{\circ} \mathrm{C}$, only the mature metaphase II oocytes were selected for injection by ICSI, using the microscope Integra 3 micromanipulator (CooperSurgical Fertility Company, Denmark) [23].

\section{Fertilization and Embryo Assessment}

Zygotes were evaluated and graded from 1 to 5 after 16-18 h post-ICSI, and embryos at day 3 were classified as grades A, $\mathrm{B}, \mathrm{C}$, and D according to the Scott scoring system [24]. The cleavage score of each patient was calculated as follows: the sum of cleavage scores of embryos/the total number of embryos, where embryos at day 3 with 8 cells were given 4 points, embryos with 6 cells were given 3 points, and embryos with 4 cells were given 2 . The cumulative quality score of the embryos for each patient was calculated as follows: the sum of scores of embryos/the total number of embryos, where embryos with grade A were given 3 points, embryos with grade B were given 2 points, and embryos with grade $\mathrm{C}$ were given only 1 point [25].

\section{Sperm mtDNA Extraction}

Genomic DNA was extracted from the purified samples using a commercial kit (QIAamp DNA Mini Kit, Qiagen, Germany); then, mtDNA was amplified using the REPLI-g Mitochondrial DNA Kit (Qiagen, Germany). Using the Nanodrop spectrophotometer ND-2000c (Thermo Scientific, USA), only the isolated DNA with an optimal density ratio of $260 / 280$ of 1.8 or more was chosen and stored at $-20^{\circ} \mathrm{C}$.

\section{PCR}

To amplify the ND1, ND2, ND5 and ND6 genes, 4 sets of polymerase chain reaction (PCR) primers (forward and reverse) were designed using the Primer 3 program, flanking the region of each gene. Primers were designed using the human mitochondrial sequence obtained from the National Centre of Biotechnology Information (NCBI) (http://www.

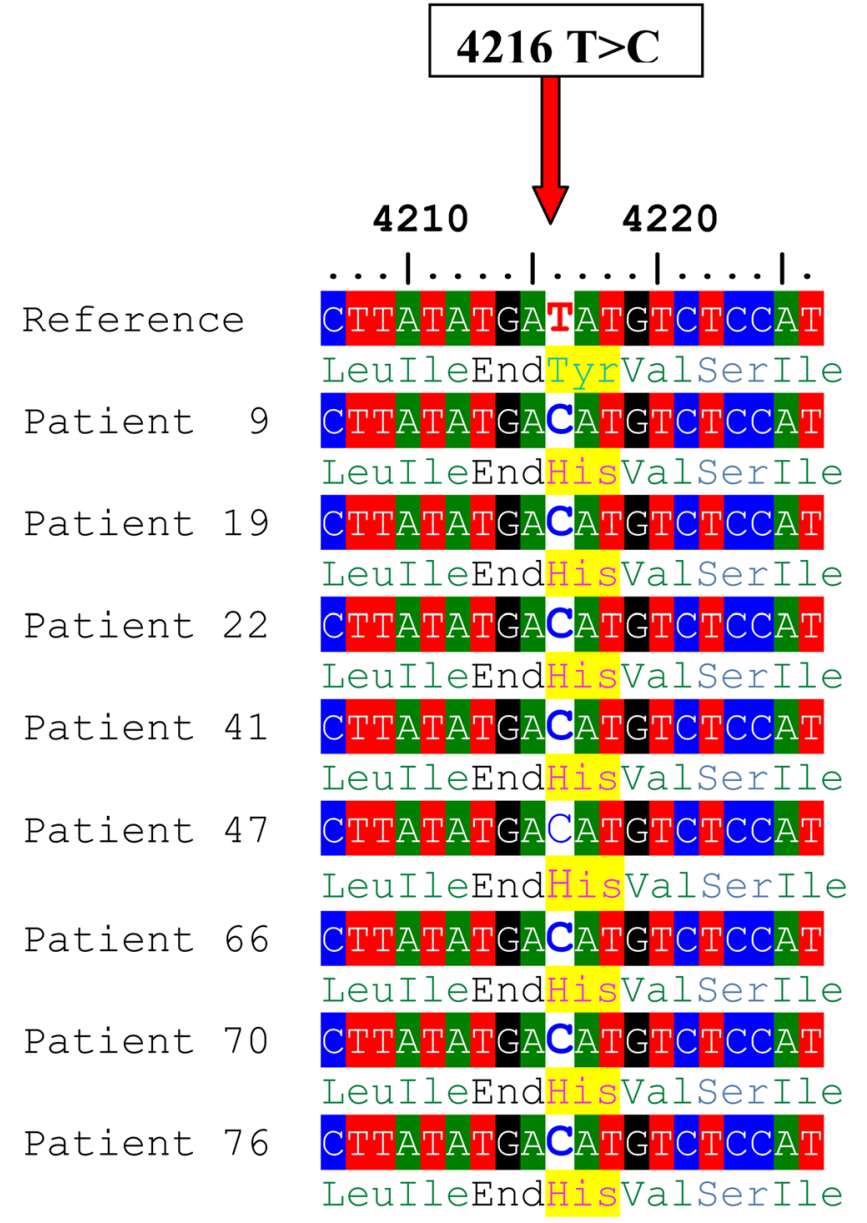

Fig. 1 Alignment of the ND1 gene sequence for 8 patients showing 4216T $>$ C nucleotide substitution. The red arrow indicates the site of nucleotide substitution, and the highlighted yellow colour indicates the amino-acid replacement (Tyr $>$ His)

ncbi.nlm.nih.gov). The oligonucleotide primers were synthesized by Microsynth Seqlab in Germany (Table 2).

A $25 \mu \mathrm{L}$ reaction mixture was prepared to contain $12.5 \mu \mathrm{L}$ PCR Master Mix (2X) (Thermo Scientific), $0.8 \mu \mathrm{L}$ of $10 \mathrm{mM}$ forward primer, $0.8 \mu \mathrm{L}$ of $10 \mathrm{mM}$ reverse primer, $2 \mu \mathrm{L}$ mtDNA $(20 \mathrm{ng} / \mu \mathrm{L})$ and $8.9 \mu \mathrm{L}$ nuclease-free water. The Thermocycler (C1000 ${ }^{\mathrm{TM}}$ Thermal cycler, Bio-Rad, USA) program was set as follows: initial denaturing at $95^{\circ} \mathrm{C}$ for $3 \mathrm{~min}$,

Table 4 The percentages of men with total mitochondrial variants in (ND1, ND2, ND5 and ND6) genes among controls and different asthenozoospermic groups

\begin{tabular}{|c|c|c|c|c|c|c|}
\hline & Group $1(N=35)$ & Group $2(\mathrm{~N}=35)$ & Group $3(\mathrm{~N}=35)$ & Controls $(N=45)$ & & \\
\hline Gene & $\begin{array}{l}\text { Number of males with total } \\
\text { variants (percentage) }\end{array}$ & $\begin{array}{l}\text { Number of males with total } \\
\text { variants (percentage) }\end{array}$ & $\begin{array}{l}\text { Number of males with total } \\
\text { variants (percentage) }\end{array}$ & $\begin{array}{l}\text { Number of males with total } \\
\text { variants (percentage) }\end{array}$ & $\begin{array}{l}X^{2}(3, N= \\
150)\end{array}$ & $\begin{array}{l}P \\
\text { value }\end{array}$ \\
\hline ND1 & $28(80.0 \%)$ & $9(25.7 \%)$ & $6(17.1 \%)$ & $7(15.6 \%)$ & 47.9 & 0.0001 \\
\hline ND2 & $21(60.0 \%)$ & $11(31.4 \%)$ & $8(22.9 \%)$ & $6(13.3 \%)$ & 21.5 & 0.0008 \\
\hline ND5 & $32(91.4 \%)$ & $27(77.1 \%)$ & $15(42.9 \%)$ & $8(17.8 \%)$ & 52.9 & 0.0001 \\
\hline ND6 & $16(45.7 \%)$ & $11(31.4 \%)$ & $6(17.1 \%)$ & $6(13.3 \%)$ & 12.8 & 0.0051 \\
\hline
\end{tabular}



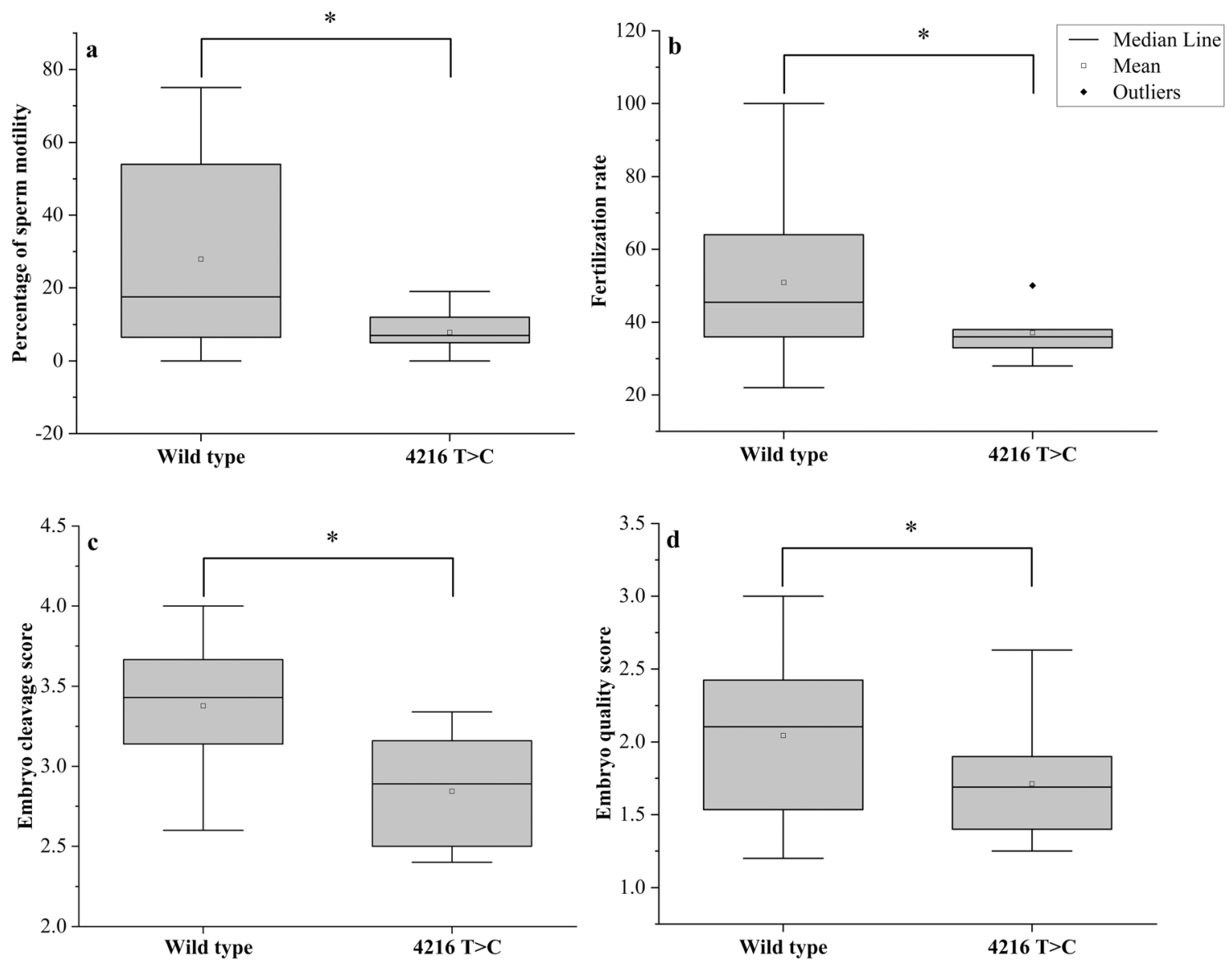

Fig. 2 Box plots showing the differences between men with or without the 4216T >C. a Difference in sperm motility, $b$ difference in fertilization rate, $\mathbf{c}$ difference in embryo cleavage score, and $\mathbf{d}$ difference in embryo

quality score. Mann-Whitney $P$ values for the differences in the medians were $0.012,0.013,0.044$, and 0.041 , respectively. $* P<0.05$

followed by 35 cycles of denaturation at $95{ }^{\circ} \mathrm{C}$ for $30 \mathrm{~s}$, an$64{ }^{\circ} \mathrm{C}$ ), an extension of primers at $72{ }^{\circ} \mathrm{C}$ for $N D 1$ and $N D 2$ : nealing for $40 \mathrm{~s}\left(N D 1: 59^{\circ} \mathrm{C} ; N D 2\right.$ and $N D 6: 61{ }^{\circ} \mathrm{C} ; N D 5$ :

$1 \mathrm{~min}$; ND5: $2 \mathrm{~min}$; ND6: $45 \mathrm{~s}$ ), then a final extension for

Table 5 The mtDNA variants identified in the ND2 gene

\begin{tabular}{cllllll}
\hline $\begin{array}{l}\text { Serial } \\
\text { number }\end{array}$ & $\begin{array}{l}\text { MtDNA } \\
\text { variant }\end{array}$ & $\begin{array}{l}\text { Amino acid } \\
\text { change }\end{array}$ & $\begin{array}{l}\text { Frequency of } \\
\text { variant in control }\end{array}$ & $\begin{array}{l}\text { Frequency of variant in } \\
\text { asthenozoospermia }\end{array}$ & $\begin{array}{l}\text { G } \\
\text { test }\end{array}$ & $\begin{array}{l}P \\
\text { value }\end{array}$ \\
\hline 1 & $4769 \mathrm{~A}>\mathrm{G}$ & Met $>$ Met & $2 / 45$ & $12 / 105$ & 2.061 & 0.151 \\
2 & $4917 \mathrm{~A}>\mathrm{G}$ & Asn $>$ Asp & $1 / 45$ & $11 / 105$ & 3.601 & 0.058 \\
3 & $4733 \mathrm{~T}>\mathrm{C}$ & Asn $>$ Asn & $0 / 45$ & $1 / 105$ & 0.716 & 0.397 \\
4 & $4967 \mathrm{~T}>\mathrm{C}$ & Ser $>$ Ser & $0 / 45$ & $1 / 105$ & 0.716 & 0.397 \\
5 & $4973 \mathrm{~T}>\mathrm{C}$ & Gly $>$ Gly & $0 / 45$ & $2 / 105$ & 1.438 & 0.23 \\
6 & $4991 \mathrm{G}>\mathrm{A}$ & Gln $>$ Gln & $1 / 45$ & $4 / 105$ & 0.266 & 0.606 \\
7 & $5178 \mathrm{C}>\mathrm{A}$ & Leu $>$ Met & $0 / 45$ & $2 / 105$ & 1.438 & 0.23 \\
8 & $4646 \mathrm{~T}>\mathrm{C}$ & Tyr $>$ Tyr & $0 / 45$ & $1 / 105$ & 0.716 & 0.397 \\
9 & $5302 \mathrm{~T}>\mathrm{C}$ & Ile $>$ Thr & $0 / 45$ & $1 / 105$ & 0.716 & 0.397 \\
10 & $5417 \mathrm{G}>\mathrm{A}$ & Gln>Gln & $0 / 45$ & $1 / 105$ & 0.716 & 0.397 \\
11 & $5237 \mathrm{G}>\mathrm{A}$ & Pro $>$ Pro & $1 / 45$ & $1 / 105$ & 0.354 & 0.552 \\
12 & $5331 \mathrm{C}>\mathrm{A}$ & Leu>Ile & $0 / 45$ & $1 / 105$ & 0.716 & 0.397 \\
13 & $4561 \mathrm{~T}>\mathrm{C}$ & Val $>$ Ala & $0 / 45$ & $1 / 105$ & 0.716 & 0.397 \\
14 & $4823 \mathrm{~T}>\mathrm{C}$ & Val $>$ Val & $1 / 45$ & $4 / 105$ & 0.266 & 0.606 \\
15 & $5147 \mathrm{G}>\mathrm{A}$ & Thr $>$ Thr & $0 / 45$ & $1 / 105$ & 0.716 & 0.397 \\
16 & $4639 \mathrm{~T}>\mathrm{C}$ & Ile $>$ Thr & $0 / 45$ & $2 / 105$ & 1.438 & 0.23 \\
17 & $4883 \mathrm{C}>\mathrm{T}$ & Pro $>$ Pro & $0 / 45$ & $1 / 105$ & 0.716 & 0.397 \\
18 & $4703 \mathrm{~T}>\mathrm{C}$ & Asn $>$ Asn & $1 / 45$ & $0 / 105$ & 2.424 & 0.12 \\
19 & $5004 \mathrm{~T}>\mathrm{C}$ & Leu>Leu & $1 / 45$ & $0 / 105$ & 2.424 & 0.12 \\
20 & $4640 \mathrm{C}>\mathrm{A}$ & Ile $>$ Met & $0 / 45$ & $1 / 105$ & 0.716 & 0.397 \\
21 & $5048 \mathrm{~T}>\mathrm{C}$ & Val $>$ Val & $1 / 45$ & $1 / 105$ & 0.354 & 0.552 \\
\hline
\end{tabular}


Table 6 The mtDNA variants identified in the ND5 gene

Serial number MtDNA variant Amino acid change Frequency of variant in control Frequency of variant in asthenozoospermia G test $P$ value

\begin{tabular}{|c|c|c|c|c|c|c|}
\hline 1 & $13708 \mathrm{G}>\mathrm{A}^{*}$ & Ala $>\mathrm{Thr}$ & $1 / 45$ & $15 / 105$ & 6.131 & $0.013^{*}$ \\
\hline 2 & $13879 \mathrm{~T}>\mathrm{C}$ & Ser $>$ Pro & $0 / 45$ & $1 / 105$ & 0.716 & 0.397 \\
\hline 3 & $13965 \mathrm{~T}>\mathrm{C}$ & Leu>Leu & $0 / 45$ & $1 / 105$ & 0.716 & 0.397 \\
\hline 4 & $13966 \mathrm{~A}>\mathrm{G}$ & Thr $>$ Ala & $0 / 45$ & $1 / 105$ & 0.716 & 0.397 \\
\hline 5 & $13967 \mathrm{C}>\mathrm{T}$ & Thr $>$ Met & $0 / 45$ & $1 / 105$ & 0.716 & 0.397 \\
\hline 6 & $13928 \mathrm{G}>\mathrm{C}$ & Ser>Asn & $0 / 45$ & $1 / 105$ & 0.716 & 0.397 \\
\hline 7 & $13734 \mathrm{~T}>\mathrm{C}$ & Phe $>$ Phe & $0 / 45$ & $1 / 105$ & 0.716 & 0.397 \\
\hline 8 & $14040 \mathrm{G}>\mathrm{A}$ & $\mathrm{Gln}>\mathrm{G} \ln$ & $0 / 45$ & $4 / 105$ & 2.9 & 0.089 \\
\hline 9 & $14070 \mathrm{~A}>\mathrm{G}$ & Ser $>$ Ser & $1 / 45$ & $3 / 105$ & 0.051 & 0.822 \\
\hline 10 & $13650 \mathrm{C}>\mathrm{T}$ & Pro $>$ Pro & $0 / 45$ & $3 / 105$ & 2.166 & 0.141 \\
\hline 11 & $13752 \mathrm{~T}>\mathrm{C}$ & Ile>Ile & $0 / 45$ & $1 / 105$ & 0.716 & 0.397 \\
\hline 12 & $13803 \mathrm{~A}>\mathrm{G}$ & $\mathrm{Thr}>\mathrm{Thr}$ & $0 / 45$ & $2 / 105$ & 1.438 & 0.23 \\
\hline 13 & $14059 \mathrm{~A}>\mathrm{G}$ & Ile>Val & $0 / 45$ & $1 / 105$ & 0.716 & 0.397 \\
\hline 14 & $13780 \mathrm{~A}>\mathrm{G}$ & Ile $>$ Val & $0 / 45$ & $1 / 105$ & 0.716 & 0.397 \\
\hline 15 & $14053 \mathrm{~A}>\mathrm{G}$ & Thr $>$ Ala & $0 / 45$ & $1 / 105$ & 0.716 & 0.397 \\
\hline 16 & $14110 \mathrm{~T}>\mathrm{C}$ & Phe $>$ Leu & $1 / 45$ & $1 / 105$ & 0.354 & 0.552 \\
\hline 17 & $13762 \mathrm{~T}>\mathrm{G}$ & Ser $>$ Ala & $0 / 45$ & $2 / 105$ & 1.438 & 0.23 \\
\hline 18 & $12372 \mathrm{G}>\mathrm{A}$ & Leu $>$ Leu & $6 / 45$ & $18 / 105$ & 0.35 & 0.554 \\
\hline 19 & $12705 \mathrm{C}>\mathrm{T}$ & Ile>Ile & $0 / 45$ & $14 / 105$ & 10.593 & 0.001 \\
\hline 20 & $12850 \mathrm{~A}>\mathrm{G}$ & Ile>Val & $0 / 45$ & $3 / 105$ & 2.166 & 0.141 \\
\hline 21 & $12822 \mathrm{~A}>\mathrm{G}$ & Ala $>$ Ala & $0 / 45$ & $4 / 105$ & 2.9 & 0.089 \\
\hline 22 & $12406 \mathrm{G}>\mathrm{A}$ & Val>Ile & $0 / 45$ & $1 / 105$ & 0.716 & 0.397 \\
\hline 23 & $13722 \mathrm{~A}>\mathrm{G}$ & Leu $>$ Leu & $1 / 45$ & $1 / 105$ & 0.354 & 0.552 \\
\hline 24 & $12346 \mathrm{C}>\mathrm{T}$ & His>Tyr & $0 / 45$ & $2 / 105$ & 1.438 & 0.23 \\
\hline 25 & $12403 \mathrm{C}>\mathrm{T}$ & Leu $>$ Phe & $0 / 45$ & $2 / 105$ & 1.438 & 0.23 \\
\hline 26 & $12414 \mathrm{~T}>\mathrm{C}$ & Pro $>$ Pro & $0 / 45$ & $2 / 105$ & 1.438 & 0.23 \\
\hline 27 & $12612 \mathrm{~A}>\mathrm{G}$ & Val>Val & $0 / 45$ & $8 / 105$ & 5.898 & 0.015 \\
\hline 28 & $12501 \mathrm{G}>\mathrm{A}$ & Met $>$ Met & $2 / 45$ & $3 / 105$ & 0.234 & 0.629 \\
\hline 29 & $12693 \mathrm{~A}>\mathrm{G}$ & Lys $>$ Lys & $0 / 45$ & $1 / 105$ & 0.716 & 0.397 \\
\hline 30 & $12950 \mathrm{~A}>\mathrm{G}$ & Asn $>$ Thr & $0 / 45$ & $1 / 105$ & 0.716 & 0.397 \\
\hline 31 & $12408 \mathrm{~T}>\mathrm{C}$ & Val>Val & $0 / 45$ & $1 / 105$ & 0.716 & 0.397 \\
\hline 32 & $13368 \mathrm{G}>\mathrm{A}$ & Gly $>$ Gly & $1 / 45$ & $13 / 105$ & 4.83 & 0.028 \\
\hline 33 & $13020 \mathrm{~T}>\mathrm{C}$ & Gly $>$ Gly & $0 / 45$ & $1 / 105$ & 0.716 & 0.397 \\
\hline 34 & $13215 \mathrm{~T}>\mathrm{C}$ & Leu>Leu & $0 / 45$ & $1 / 105$ & 0.716 & 0.397 \\
\hline 35 & $13702 \mathrm{C}>\mathrm{G}$ & Arg $>$ Gly & $0 / 45$ & $1 / 105$ & 0.716 & 0.397 \\
\hline 36 & $13392 \mathrm{~T}>\mathrm{C}$ & Asn $>$ Asn & $0 / 45$ & $2 / 105$ & 1.438 & 0.23 \\
\hline 37 & $13104 \mathrm{~A}>\mathrm{G}$ & Gly>Gly & $1 / 45$ & $5 / 105$ & 0.589 & 0.443 \\
\hline 38 & $13422 \mathrm{~A}>\mathrm{G}$ & Leu>Leu & $0 / 45$ & $2 / 105$ & 1.438 & 0.23 \\
\hline 39 & $13145 \mathrm{G}>\mathrm{A}$ & Ser>Asn & $1 / 45$ & $2 / 105$ & 0.016 & 0.9 \\
\hline 40 & $13326 \mathrm{~T}>\mathrm{C}$ & Cys $>$ Cys & $0 / 45$ & $1 / 105$ & 0.716 & 0.397 \\
\hline 41 & $13188 \mathrm{C}>\mathrm{T}$ & $\mathrm{Thr}>\mathrm{Thr}$ & $0 / 45$ & $1 / 105$ & 0.716 & 0.397 \\
\hline 42 & $13590 \mathrm{G}>\mathrm{A}$ & Leu $>$ Leu & $0 / 45$ & $2 / 105$ & 1.438 & 0.23 \\
\hline 43 & $13650 \mathrm{C}>\mathrm{T}$ & Pro $>$ Pro & $0 / 45$ & $2 / 105$ & 1.438 & 0.23 \\
\hline 44 & $13188 \mathrm{C}>\mathrm{T}$ & Thr $>$ Thr & $0 / 45$ & $1 / 105$ & 0.716 & 0.397 \\
\hline 45 & $13780 \mathrm{~A}>\mathrm{G}$ & Ile>Val & $1 / 45$ & $0 / 105$ & 2.424 & 0.12 \\
\hline 46 & $13981 \mathrm{C}>\mathrm{T}$ & Pro $>$ Ser & $0 / 45$ & $1 / 105$ & 0.716 & 0.397 \\
\hline 47 & $14025 \mathrm{~T}>\mathrm{C}$ & Pro $>$ Pro & $0 / 45$ & $1 / 105$ & 0.716 & 0.397 \\
\hline 48 & $14034 \mathrm{~T}>\mathrm{C}$ & Ile>Ile & $0 / 45$ & $1 / 105$ & 0.716 & 0.397 \\
\hline 49 & $12630 \mathrm{G}>\mathrm{A}$ & $\operatorname{Tr} p>\operatorname{Tr} p$ & $0 / 45$ & $1 / 105$ & 0.716 & 0.397 \\
\hline
\end{tabular}


Table 6 (continued)

Serial number MtDNA variant Amino acid change Frequency of variant in control Frequency of variant in asthenozoospermia G test $P$ value

\begin{tabular}{lllllll}
\hline 50 & $12654 \mathrm{~A}>\mathrm{G}$ & Trp>Trp & $0 / 45$ & $1 / 105$ & 0.716 & 0.397 \\
51 & $12681 \mathrm{~T}>\mathrm{C}$ & Asn>Asn & $0 / 45$ & $1 / 105$ & 0.716 & 0.397 \\
52 & $13542 \mathrm{~A}>\mathrm{G}$ & Ser>Ser & $0 / 45$ & $1 / 105$ & 0.716 & 0.397 \\
53 & $13617 \mathrm{~T}>\mathrm{C}$ & Ile>Ile & $0 / 45$ & $1 / 105$ & 0.716 & 0.397 \\
54 & $13821 \mathrm{C}>\mathrm{T}$ & PhePhe & $0 / 45$ & $3 / 105$ & 2.166 & 0.141 \\
55 & $12506 \mathrm{~T}>\mathrm{A}^{*}$ & Leu>Gln & $0 / 45$ & $6 / 105$ & 4.386 & $0.036^{*}$ \\
56 & $12879 \mathrm{~T}>\mathrm{C}$ & Gly>Gly & $0 / 45$ & $3 / 105$ & 2.166 & 0.141 \\
\hline
\end{tabular}

* Statistically significant difference, $P$ value $<0.05$

5 min at $72{ }^{\circ} \mathrm{C}$. To check the amplification, $5 \mu \mathrm{L}$ of each PCR product was run on $1 \%$ agarose gel stained with SYBR Safe stain (Invitrogen) and then visualized using Molecular Imager Gel Doc XR+ (Bio-Rad).

\section{Identification of Genetic Variants in ND1, ND2, ND5, and ND6}

PCR products were purified and sequenced using the Sanger method (Microsynth Seqlab, Germany). Sequencing was carried out in both directions (forward and reverse) for each sample. For the ND5 gene, two additional internal primers were designed, namely, ND5A and ND5B (Table 1).

The primary and secondary sequences for each sample were analyzed using the BioEdit sequence alignment editor version 7.2.5 and aligned to the NCBI reference sequences (NC_012920.1).

To predict the possible impact of amino-acid substitution on protein structure and function, and to evaluate the possible damaging effect of genetic variants; two versions of software were used (The American College of Medical Genetics and Genomics (ACMG),https://www.acmg.net and Poly Phenyl2, http://genetics.bwh.harvard.edu/pph2.

\section{Statistical Analysis}

Statistical analysis was carried out using the OriginPro, Version 2020 (OriginLab Corporation, Northampton, MA, USA). The normality assumptions were checked for the variables in question and were found not to be fitted by a normal distribution, and hence, non-parametric tests were applied to our study. The Kruskal-Wallis $\mathrm{H}$ test alongside the Mann-Whitney $U$ test in addition to chi-square were used to determine if there were statistically significant differences between two or more groups of an independent variable on a continuous or ordinal dependent variable. Spearman's rho, a non-parametric test, was used to measure the strength of association between two variables. Odds ratio and their $95 \%$ confidence intervals were determined, and some descriptive statistics and graphs for the variables in question were presented. A $P$ value $<0.05$ was considered to be statistically significant.

\section{Results}

A total of 29 nucleotide substitutions (SNPs) in the ND1 gene were identified; six of them were missense, while 23 were synonymous (Table 3 ). The percentages of men with total variants in the $N D 1$ gene among groups 1,2,3, and the control were: $80 \%, 25.7 \%, 17.1 \%$, and $15.6 \%$, respectively, $P=$ 0.0001 (Table 4). Only one variant 4216T $>C$ (rs1599988)

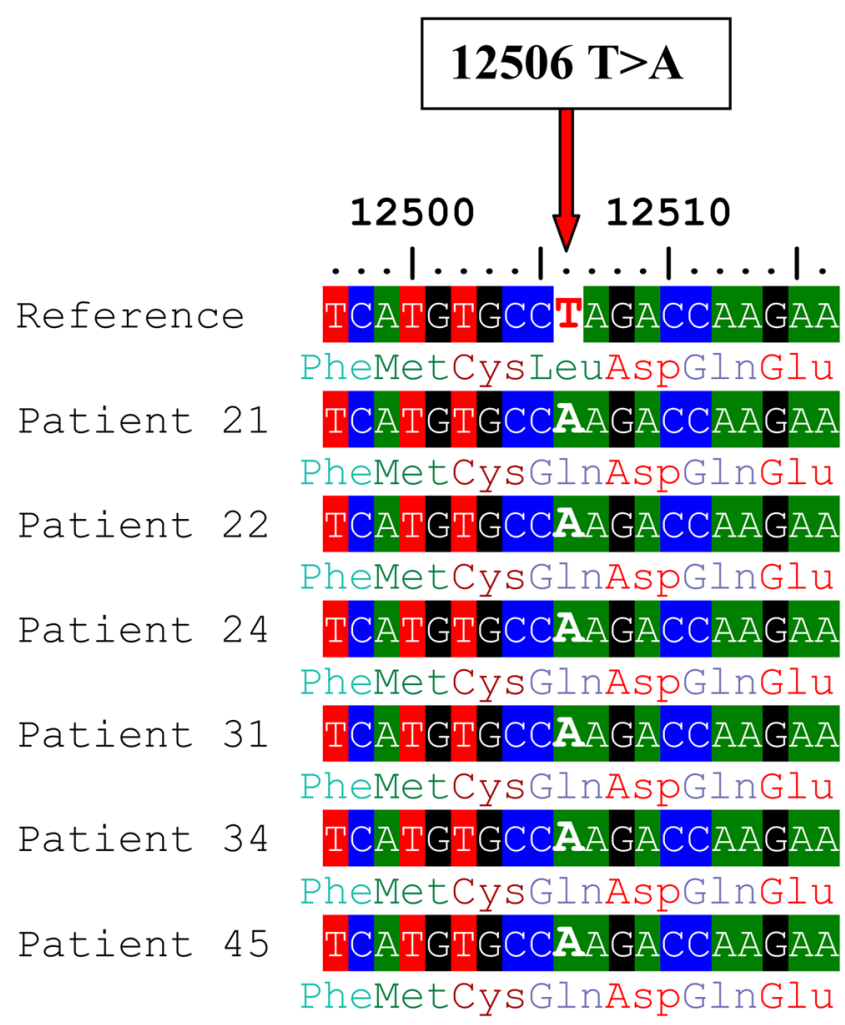

Fig. 3 Alignment of the ND5 gene sequence for 6 patients showing the novel $12506 \mathrm{~T}>\mathrm{A}$ variant. The red arrow indicates the site of nucleotide substitution causing an amino acid replacement (Leu>Gln) 
was significantly different between cases and controls ( $P$ value $=0.006)$. The percentages of men with $4216 \mathrm{~T}>\mathrm{C}$ among groups 1,2 , and 3 were $14.3 \%, 8.6 \%$, and $5.8 \%$, respectively $(P=0.005)$, while it was not found among the control. This variant caused Tyr $>$ His amino acid substitution (Fig. 1). According to ACMG and Poly Phenyl-2, it is predicted that this variant is benign (score 0.001 , sensitivity 0.99 ; specificity $0.15)$. It was identified among 10 asthenozoospermic patients in a homoplasmic state while it was not found among control group. The medians of sperm motility were (wild type (17.5 \pm $25.21), 4216 \mathrm{~T}>\mathrm{C}(7 \pm 6.1), P=0.012)$, fertilization rate (wild type $(45.5 \pm 18.08,4216 \mathrm{~T}>\mathrm{C}(36 \pm 7.61), P=0.013)$, embryo cleavage score (wild type $(3.42 \pm 0.37), 4216 \mathrm{~T}>\mathrm{C}(3.07 \pm$ $0.12), P=0.044)$, and embryo quality score (wild type (2.11 $\pm 0.49), 4216 \mathrm{~T}>\mathrm{C}(1.69 \pm 0.41), P=0.041)$ (Fig. 2).

A total of 21 nucleotide substitutions in the ND2 gene were identified; six of them were missense, and 15 were synonymous (Table 5). The percentages of men with total variants in the ND2 gene among groups 1,2,3, and in the control were $60 \%, 31.4 \%, 22.9 \%$, and $13.3 \%$, respectively, $P=0.0008$
(Table 4). However, none of these variants were significantly different between the 2 groups ( $P$ value $>0.05)$.

A total of 19 missense variants and 37 synonymous variants were identified in the ND5 gene (Table 6). The percentages of men with total variants in the ND5 gene among groups $1,2,3$, and the control were $91.4 \%, 77.1 \%, 42.9 \%$, and $17.8 \%$, respectively, $P=0.0001$ (Table 4 ). All of these variants had been previously reported in the NCBI (https:/www.ncbi. nlm.nih.gov/) and in the human mitochondrial DNA database (www.mitomap.org), except for a novel variant at the locus 12506. This variant was identified in 6 asthenozoospermic patients (all were heteroplasmic), also the percentages of men with 12506T $>$ A among groups 1, 2 and were 14.3\%, 2 . $9 \%$ respectively, $P=0.0001$ while it was not found among group 3 and the control. We reported the nucleotide sequences of 6 patients (BankIt2363991 ND5_21, BankIt2363991 ND5_22, BankIt2363991 ND5_24, BankIt2363991 ND5_31, BankIt2363991 ND5_34 and BankIt2363991 ND5_45) to the GenBank and the following accession numbers were given, respectively (MT742299,

\section{PolyPhen-2 report for P03915 L57Q}

\section{Query}

Protein Acc Position $A_{1} A_{1} A_{2}$ Description Canonical; RecName: Full=NADH-ubiquinone oxidoreductase P03915

$57 \quad \mathrm{~L} \quad \mathrm{Q}$
chain 5; $E C=1.6 .5 .3$; AltName: Full=NADH dehydrogenase subunit 5; Length: 603

\section{Results}

Prediction/Confidence

PolyPhen-2 v2.2.2r398

\section{HumDiv}

This mutation is predicted to be POSSIBLY DAMAGING with a score of 0.937 (sensitivity: 0.80; specificity: 0.94)

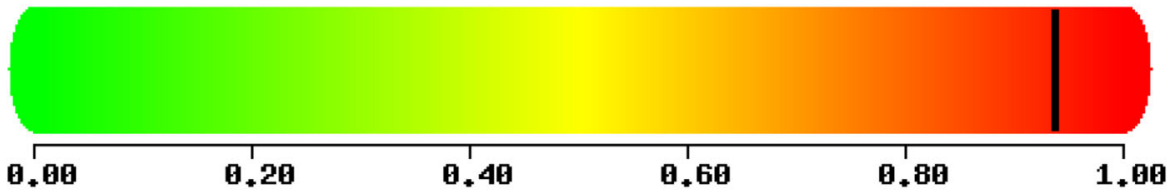

\section{HumVar}

This mutation is predicted to be POSSIBLY DAMAGING with a score of 0.663 (sensitivity: 0.79; specificity: 0.84)

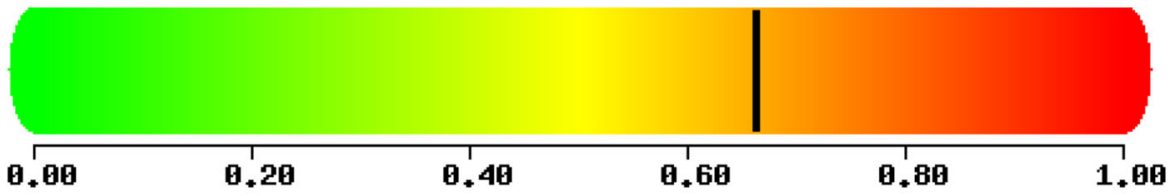

Fig. 4 Prediction of the functional effect of 12506T >A substitution by Poly Phenyl-2 software 
MT742300, MT742301, MT742302, MT742303 and MT742304). The novel SNP 12506T $>\mathrm{A}$ is a missense variant that replaced Gln by Leu (Fig. 3). This variant is significantly different between cases and controls $(P=0$. $036)$ and is predicted to be probably damaging according to the Poly Phenyl-2 and ACMG (score 0.663 , sensitivity 0.79 ; specificity 0.84) (Fig. 4). The medians of sperm motility (wild type (17.5 \pm 24.93$), 12506 \mathrm{~T}>\mathrm{A}(4.5 \pm 24.93), P=0.009)$, fertilization rate (wild type $(46 \pm 17.8), 12506 \mathrm{~T}>\mathrm{A}(32 \pm 2.13)$, $P=0.001)$, embryo cleavage score (wild type $(3.42 \pm 0.37)$, $12506 \mathrm{~T}>\mathrm{A}(3.07 \pm 0.12), P=0.044)$, embryo quality score (wild type $(2.09 \pm 0.49), 12506 \mathrm{~T}>\mathrm{A}(1.62 \pm 0.22), P=0.028)$ (Fig. 5).

Another variant $13708 \mathrm{G}>\mathrm{A}(\mathrm{rs} 28359178)$ in the ND5 gene was significantly different between cases and controls $(P=$ 0.013), causing Ala $>$ Thr amino acid substitution (Fig. 6). However, this variant is predicted to be benign according to the Poly Phenyl-2 and ACMG criteria (score 0.001 , sensitivity 0.99 ; specificity 0.15 ). The $13708 \mathrm{G}>\mathrm{A}$ variant was identified among 14 asthenozoospermic men only-all were homoplasmic - while it was not found among control group. The percentages of men with $13708 \mathrm{G}>\mathrm{A}$ among groups 1,2 , and 3 were $17.1 \%, 14.3 \%$, and $8.6 \%, P=0.0012$. The medians of sperm motility (wild type $(18 \pm 25.46), 13708 \mathrm{G}>\mathrm{A}$ ( $8 \pm 7.13$ ), $P=0.043$ ), fertilization rate (wild type ( $47 \pm$ 18.09), $13708 \mathrm{G}>\mathrm{A}(36 \pm 9.55), P=0.017)$, embryo cleavage score (wild type $(3.5 \pm 0.36), 13708 \mathrm{G}>\mathrm{A}(3.0 \pm 0.24), P=$ 0.001 ), embryo quality score (wild type $(2.11 \pm 0.49)$, $13708 \mathrm{G}>\mathrm{A} 1.67 \pm 0.35), P=0.007$ ) (Fig. 7).

A total of 15 nucleotide substitutions was identified in the ND6 gene; two of them were missense, while the rest were synonymous variants (Table 7). The percentages of men with total variants in the ND6 gene among groups 1, 2, 3, and control were $45.7 \%, 31.4 \%, 17.1 \%$, and $13.3 \%$, respectively, $P=0.0051$ (Table 4). However, none of these variants were significantly different between the two groups.

The frequency of all missense variants had a significant inverse relationship with sperm motility, fertilization rate, embryo cleavage score, and embryo cleavage score $(r=-0.583$, $P=0.0001),(r=-0.576, P=0.0001),(r=-0.613, P=$ $0.0001)$, and $(r=-0.717, P=0.0001)$, respectively (Fig. 8 ). The fertilization rate had a significant positive relationship with the embryo cleavage score and the embryo quality score $(r=0.582$ and $P=0.0001)(r=0.739$ and $P=0.0001)$,
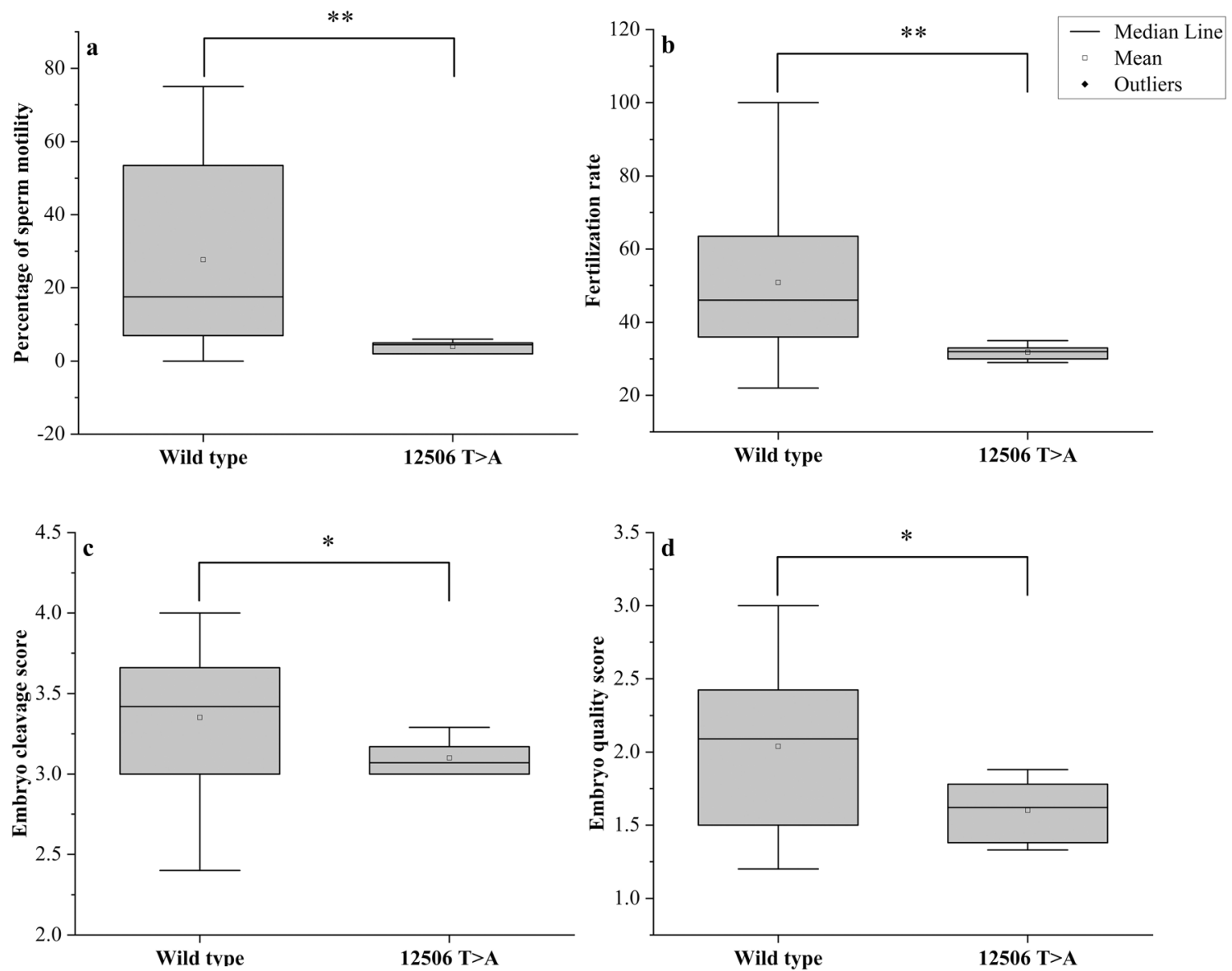

Fig. 5 Box plots showing the differences between men with or without the 12506T $>$ A. a Difference in sperm motility, b difference in fertilization rate, $\mathbf{c}$ difference in embryo cleavage score, and $\mathbf{d}$

difference in embryo quality score. Mann-Whitney $P$ values for the differences in the medians were $0.009,0.001,0.044$, and 0.028 , respectively. $* P<0.05, * * P<0.01$ 
respectively (Fig. 9). The median fertilization rates were as follows: (G1 $(36 \pm 1.86), \mathrm{G} 2(40 \pm 1.63), \mathrm{G} 3(47 \pm 13.41)$, control (67 \pm 14.69$), P<0.001)$ as illustrated in (Fig. 10).

The average embryo quality score and cleavage score among asthenozoospermic patients were 1.83 and 3.24, respectively, compared to 2.47 and 3.58 , respectively, in normozoospermic ones. A significant difference in the embryo cleavage score was detected between patients and controls $(P=0.0001)$. We also found a significant difference between the embryo quality score in the two categories $(P=0.0001)$. The median of the embryo cleavage scores were statistically different between the different groups: (G1 (3 \pm 0.31$), \mathrm{G} 2(3.34 \pm 0.36), \mathrm{G} 3$ (3.58 \pm 0.31$)$, control (3.66 \pm 0.25$), P<0.001)$, as illustrated in (Fig. 11). The median of the embryo quality scores were also statistically different: (G1 (1.5 \pm 0.31$), \mathrm{G} 2(1.75 \pm 0.39), \mathrm{G} 3$ (2.14 \pm 0.44$)$, control (2.5 \pm 0.27 ), $P<0.001$ ) (Fig. 12).

\section{Discussion}

In the present study, we found three missense variants correlated inversely with sperm motility and ICSI outcomes. Two variants, namely, 13708G $>$ A (rs28359178) in the ND5 gene and $4216 \mathrm{~T}>\mathrm{C}$ ( $\mathrm{rs} 1599988)$ in the $N D 1$, were previously reported in the NCBI (https://www.ncbi.nlm.nih.gov/) and human mitochondrial DNA database (www.mitomap.org), while we identified $12506 \mathrm{~T}>\mathrm{A}$ as a novel variant in the ND5 gene.

The variants detected in the present study have not been linked to asthenozoospermia before. However, a previous study showed that the rate of $4216 \mathrm{~T}>\mathrm{C}$ variant among diabetic patients was higher than in the controls and was statistically associated with diabetes mellitus type 2 [26]. Another study found an interesting male-specific association between the $4216 \mathrm{~T}>\mathrm{C}$ variant and the rate of infection leading to complicated sepsis and death [27].

Similarly, the $13708 \mathrm{G}>\mathrm{A}$ variant has been linked to several clinical manifestations. It has been shown that the $13708 \mathrm{G}>\mathrm{A}$ variant increases the susceptibility to multiple sclerosis [28] and found to enhance the expression of Leber hereditary optic neuropathy (LHON) disease in another study [29]. Furthermore, $13708 \mathrm{G}>\mathrm{A}$ variant was found to increase the risk for Alzheimer's disease, specifically among male patients [30].

Our results showed a negative correlation between sperm motility and the frequency of total variants, where the highest frequency of mitochondrial variants in the four genes was among group one (asthenozoospermic patients with 0 to $5 \%$ sperm motility), while the lowest frequency was among group three (asthenozoospermic patients with 16 to $35 \%$ sperm motility). The control group with normozoospermia (sperm motility between 50 and $75 \%$ ) showed a lower frequency of mitochondrial variants, compared to all patients' groups. A previous study reported that $9055 \mathrm{G}>\mathrm{A}$ in the ATPase gene and $11719 \mathrm{G}>\mathrm{A}$ in ND4 were associated with poor semen quality
[18]. Another variant $11994 \mathrm{C}>\mathrm{T}$ in ND4 gene was negatively correlated with oligoasthenozoosperima [31].

It is known that sperms require ATP for flagellar movement, and this depends on OxPhos to provide their energy requirements [3]. Here, we identified three missense variants with a significant association with sperm motility. These variants are located in the ND1 and ND5 genes, which are part of complex 1 [32]. Complex 1 plays a key role in OxPhos by receiving electrons from $\mathrm{NADH}$, and the captured energy from these electrons is utilized to release protons to the intermembrane space, and these protons are used later to generate ATP [33]. Therefore, pathogenic variants in the ND genes are expected to affect complex 1 activity, causing a deficiency in energy production, and this will negatively affect the sperm motility [7].

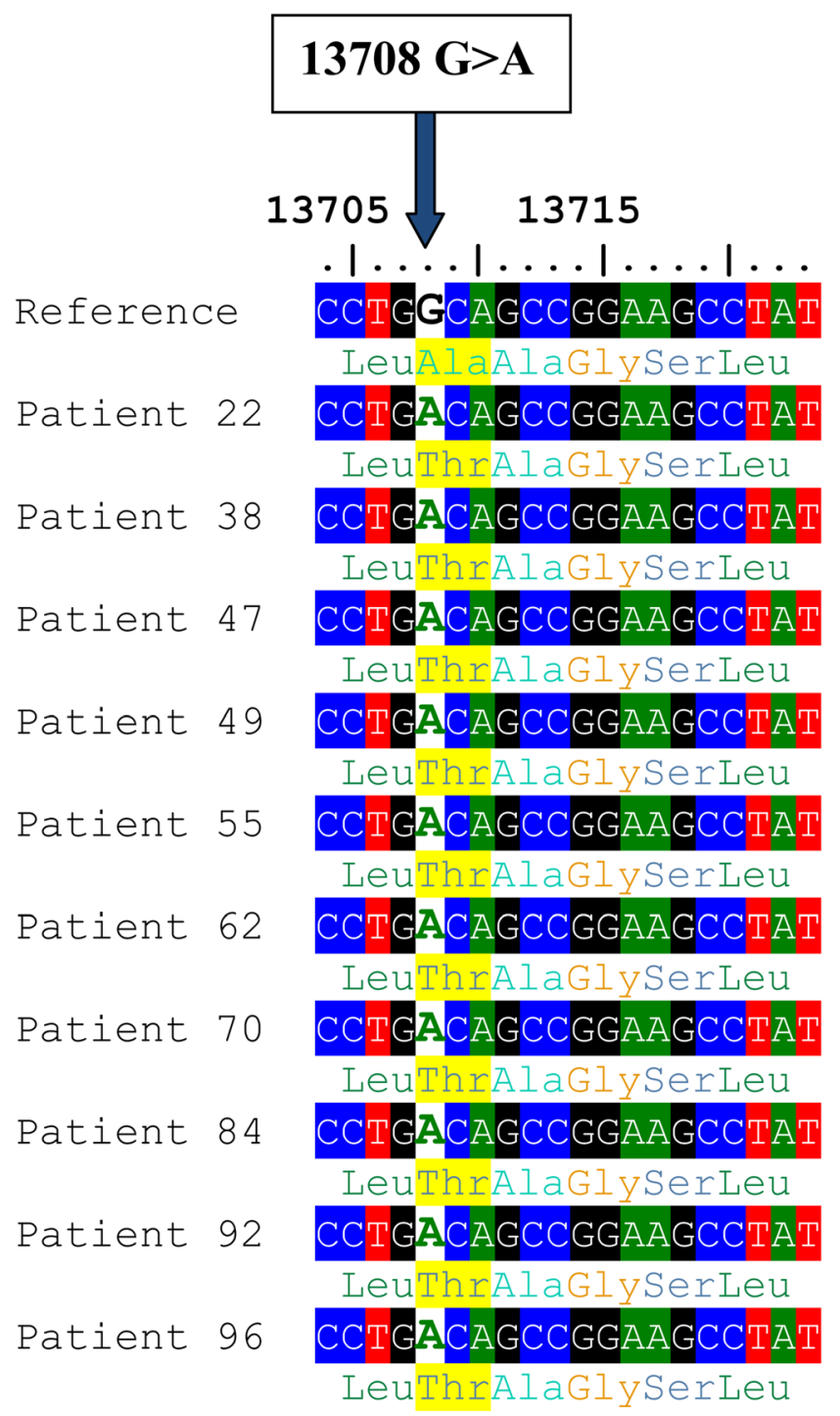

Fig. 6 Alignment of the ND5 gene sequence for 10 patients showing $13708 \mathrm{G}>\mathrm{A}$ variant. The blue arrow indicates the site of nucleotide substitution, and the highlighted yellow colour indicates the amino acid replacement (Ala>Thr) 

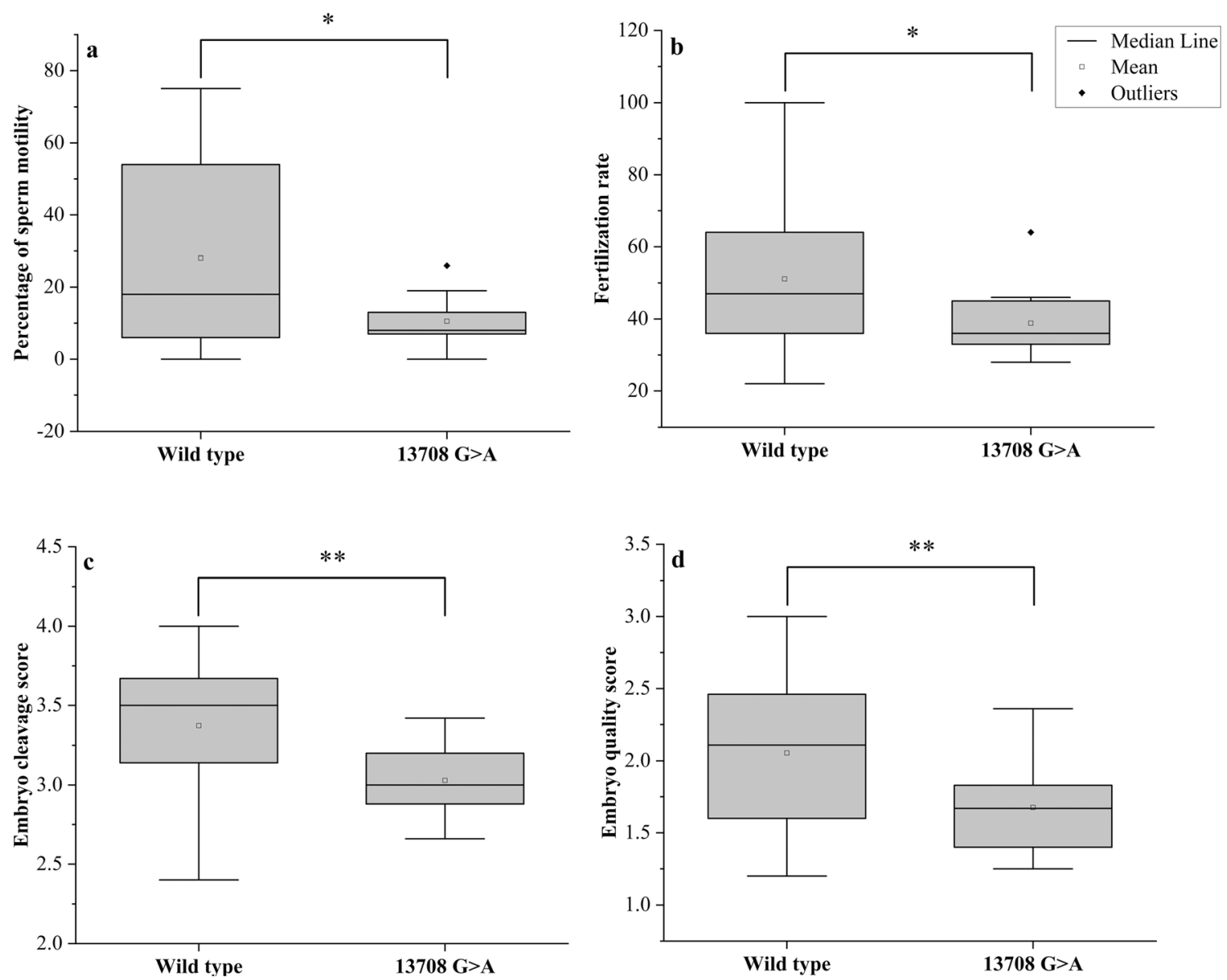

Fig. 7 Box plots showing the differences between men with or without the $13708 \mathrm{G}>\mathrm{A}$. a Difference in sperm motility, b difference in fertilization rate, c difference in embryo cleavage score, and $\mathbf{d}$

Our results demonstrated that the ICSI outcomes were correlated inversely with the load of mtDNA variants, while it had a strong positive correlation with the percentage of sperm

difference in embryo quality score. Mann-Whitney $P$ values for the differences in the medians were $0.043,0.017,0.001$, and 0.007 , respectively. ${ }^{*} P<0.05, * * P<0.01$

motility, where the fertilization rate was lower among group one compared to group three. Embryo quality, including embryo cleavage score and embryo quality score, were positively

Table 7 The mtDNA variants identified in the ND6 gene

\begin{tabular}{lllllll}
\hline $\begin{array}{l}\text { Serial } \\
\text { number }\end{array}$ & $\begin{array}{l}\text { MtDNA } \\
\text { variant }\end{array}$ & $\begin{array}{l}\text { Amino acid } \\
\text { change }\end{array}$ & $\begin{array}{l}\text { Frequency of } \\
\text { variant in control }\end{array}$ & $\begin{array}{l}\text { Frequency of variant in } \\
\text { asthenozoospermia }\end{array}$ & $\begin{array}{l}\text { G } \\
\text { test }\end{array}$ & $\begin{array}{l}P \\
\text { value }\end{array}$ \\
\hline 1 & $14167 \mathrm{C}>\mathrm{T}$ & Glu>Glu & $0 / 45$ & $4 / 105$ & 2.9 & 0.089 \\
2 & $14179 \mathrm{~A}>\mathrm{G}$ & Tyr $>$ Tyr & $1 / 45$ & $2 / 105$ & 0.016 & 0.9 \\
3 & $14182 \mathrm{~T}>\mathrm{C}$ & Val $>$ Val & $0 / 45$ & $3 / 105$ & 2.166 & 0.141 \\
4 & $14233 \mathrm{~A}>\mathrm{G}$ & Asp $>$ Asp & $2 / 45$ & $12 / 105$ & 2.061 & 0.151 \\
5 & $14323 \mathrm{G}>\mathrm{A}$ & Asp $>$ Asp & $0 / 45$ & $3 / 105$ & 2.166 & 0.141 \\
6 & $14364 \mathrm{G}>\mathrm{A}$ & Leu> $>$ Leu & $1 / 45$ & $7 / 105$ & 1.438 & 0.23 \\
7 & $14560 \mathrm{G}>\mathrm{A}$ & Val $>$ Val & $1 / 45$ & $1 / 105$ & 0.354 & 0.552 \\
8 & $14620 \mathrm{C}>\mathrm{T}$ & Gly $>$ Gly & $0 / 45$ & $1 / 105$ & 0.716 & 0.397 \\
9 & $14470 \mathrm{~T}>\mathrm{C}$ & Gly $>$ Gly & $0 / 45$ & $1 / 105$ & 0.716 & 0.397 \\
10 & $14566 \mathrm{~A}>\mathrm{G}$ & Gly $>$ Gly & $0 / 45$ & $2 / 105$ & 1.438 & 0.23 \\
11 & $14569 \mathrm{G}>\mathrm{A}$ & Ser $>$ Ser & $0 / 45$ & $2 / 105$ & 1.438 & 0.23 \\
12 & $14178 \mathrm{~T}>\mathrm{C}$ & Ile $>$ Val & $0 / 45$ & $2 / 105$ & 1.438 & 0.23 \\
13 & $14180 \mathrm{~T}>\mathrm{C}$ & Tyr $>$ Cys & $0 / 45$ & $2 / 105$ & 1.438 & 0.23 \\
14 & $14212 \mathrm{~T}>\mathrm{C}$ & Val $>$ Val & $1 / 45$ & $2 / 105$ & 0.016 & 0.9 \\
15 & $14305 \mathrm{G}>\mathrm{A}$ & Ser>Ser & $1 / 45$ & $1 / 105$ & 0.354 & 0.552 \\
\hline
\end{tabular}




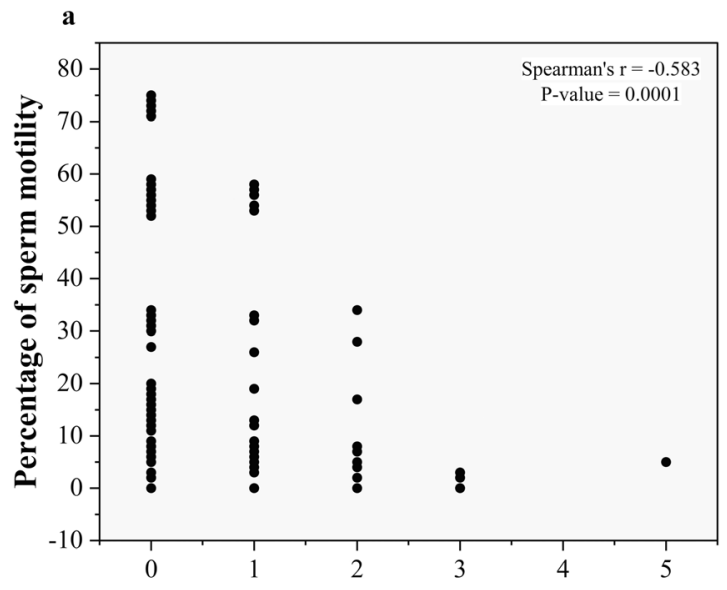

Frequency of missense variants

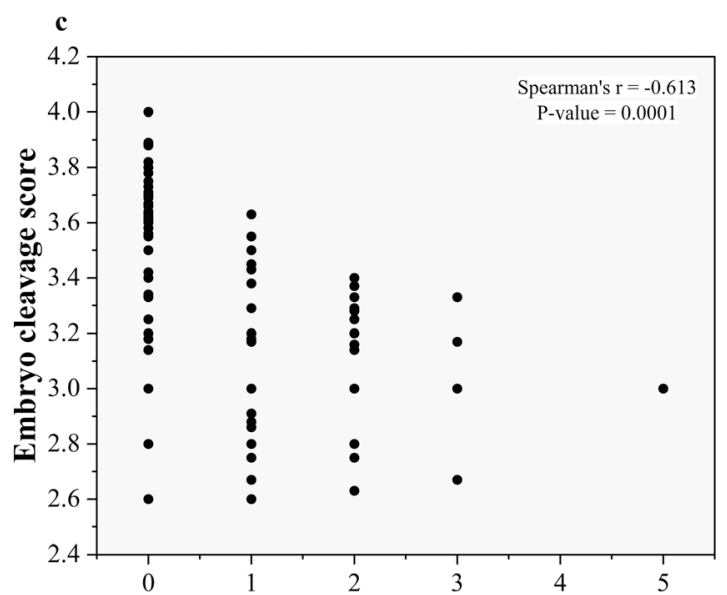

Frequency of missense variants

Fig. 8 Scatter plots of frequency of missense variants with sperm motility and ICSI outcomes. a Frequency of missense variants with sperm motility $(r=-0.583, P=0.0001)$. b Frequency of missense variants with fertilization rate $(r=-0.576, P=0.0001)$. c Frequency of missense

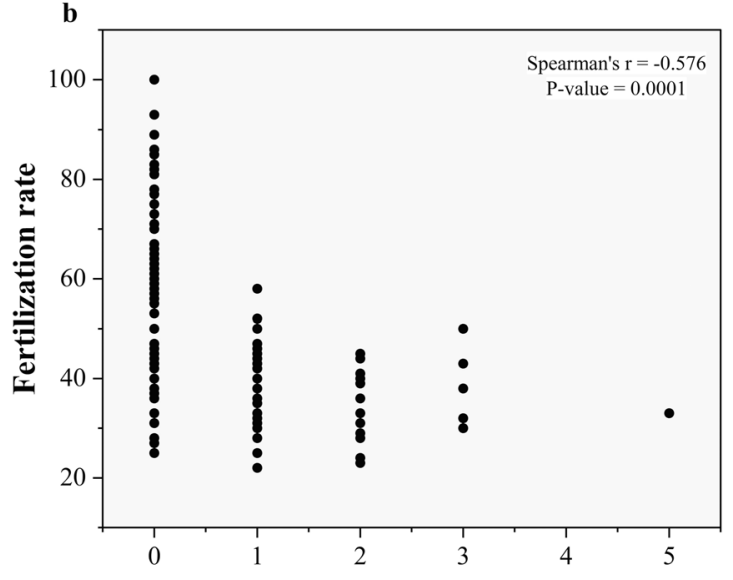

Frequency of missense variants

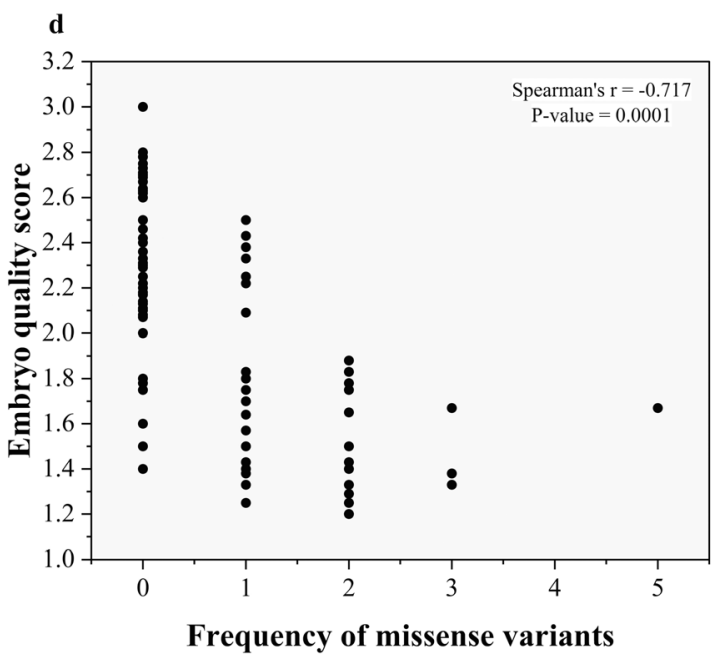

variants with embryo cleavage $\operatorname{score}(r=-0.613, \mathrm{P}=0.0001)$. d Frequency of missense variants with embryo quality score $(r=-0.717$, $P=0.0001)$

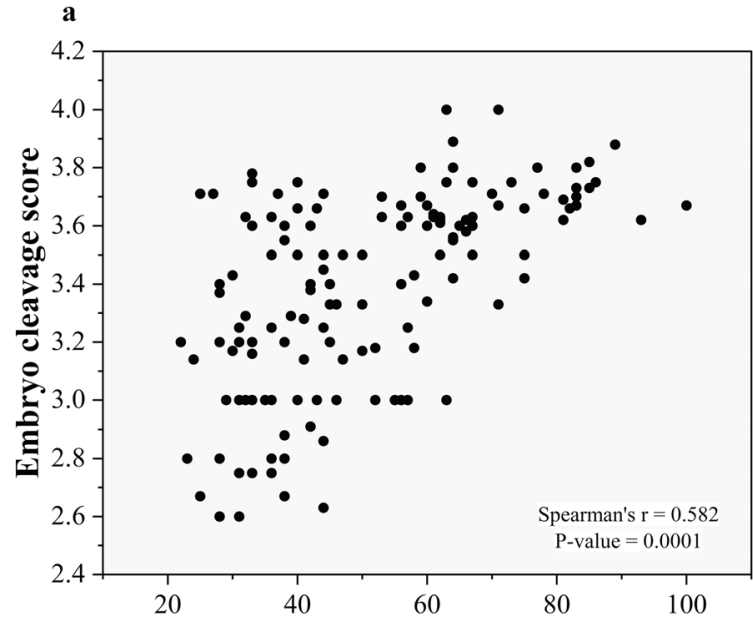

Fertilization rate

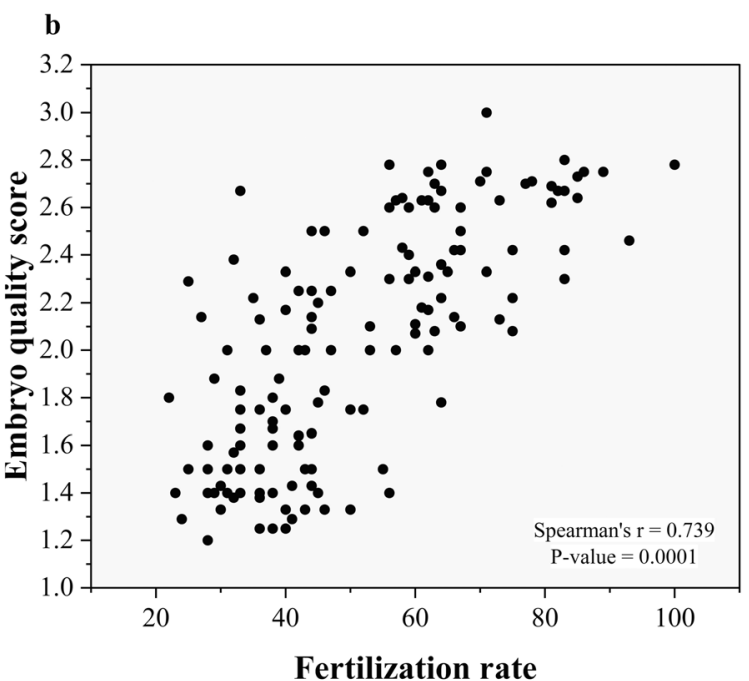

Fertilization rate

Fig. 9 a Scatter plots of fertilization rate and embryo cleavage score showing a positive correlation, $r=0.582, P=0.0001$. b Scatter plots of fertilization rate and embryo quality score showing a positive correlation, $r=0.739, P=0.0001$ 
Fig. 10 Fertilization rate among groups 1, 2, 3, and control. Kruskal-Wallis's $P$ value was included. Mann-Whitney $P$ values for the differences in the medians between all groups $<$ 0.001

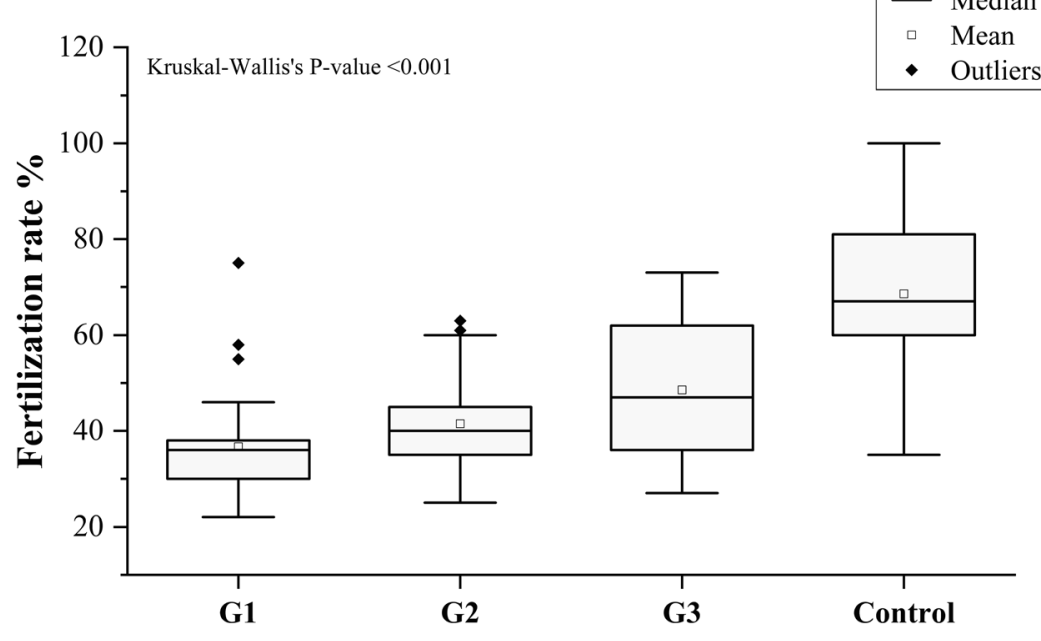

However, our results disagree with previous findings where no significant difference between the frequency of variants in mtDNA among teratozoospermia and asthenozoospermia was found [36]. However, these results do not provide conclusive evidence against the role of mtDNA in sperm motility, because of the small sample (43 samples only). The contradiction between the results of this study and other studies may be attributed to population variation. In a previous study, they found that the frequency of mtDNA SNPs varies between African American, European and Asian populations for the same mitochondrial disease [37]. Two independent studies on the association of the same SNP, namely $11994 \mathrm{C}>\mathrm{T}$, and oligoasthenozoosperima have reached different conclusions, where a strong association was found in India [31], while in the other study in Portugal no association was found [38]. The severity of the mitochondrial diseases depends on the level of heteroplasmy and the threshold value mutant mtDNA should pass in order to show pathogenic effects, which ranges between 60 and $80 \%$, based on the types of mutations and cells [4].
Fig. 11 Embryo cleavage score among groups 1, 2, 3, and control. Kruskal-Wallis's $P$ value was included. Mann-Whitney $P$ values for the differences in the medians between all groups $<$ 0.001

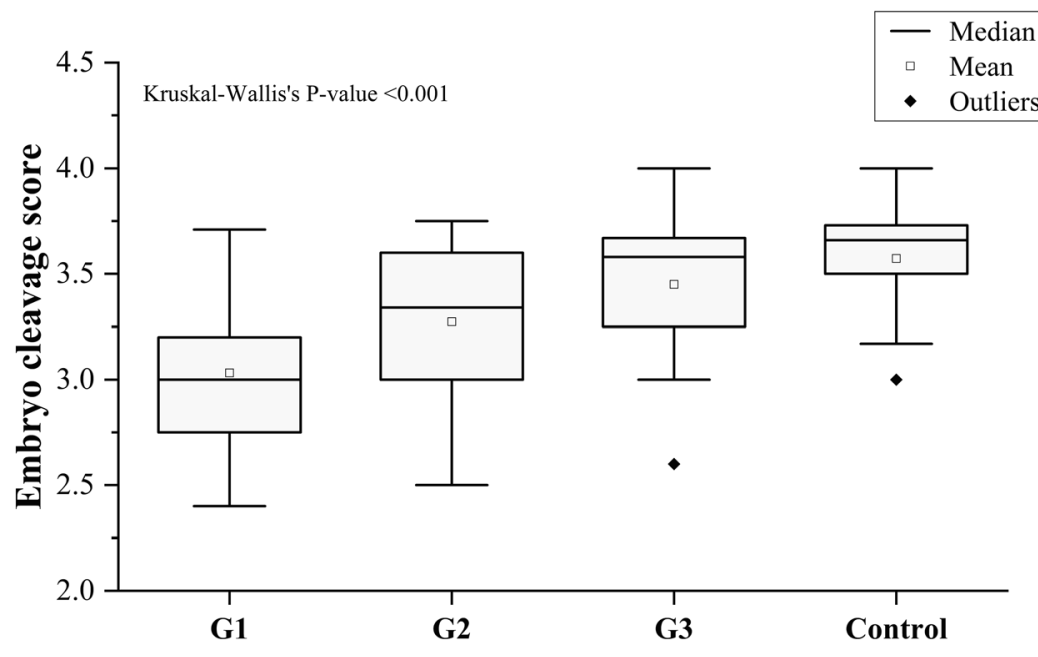


Fig. 12 Embryo quality score among the studied groups. Kruskal-Wallis's $P$ value was included, Mann-Whitney $P$ values for the differences in the medians between all groups $<$ 0.001

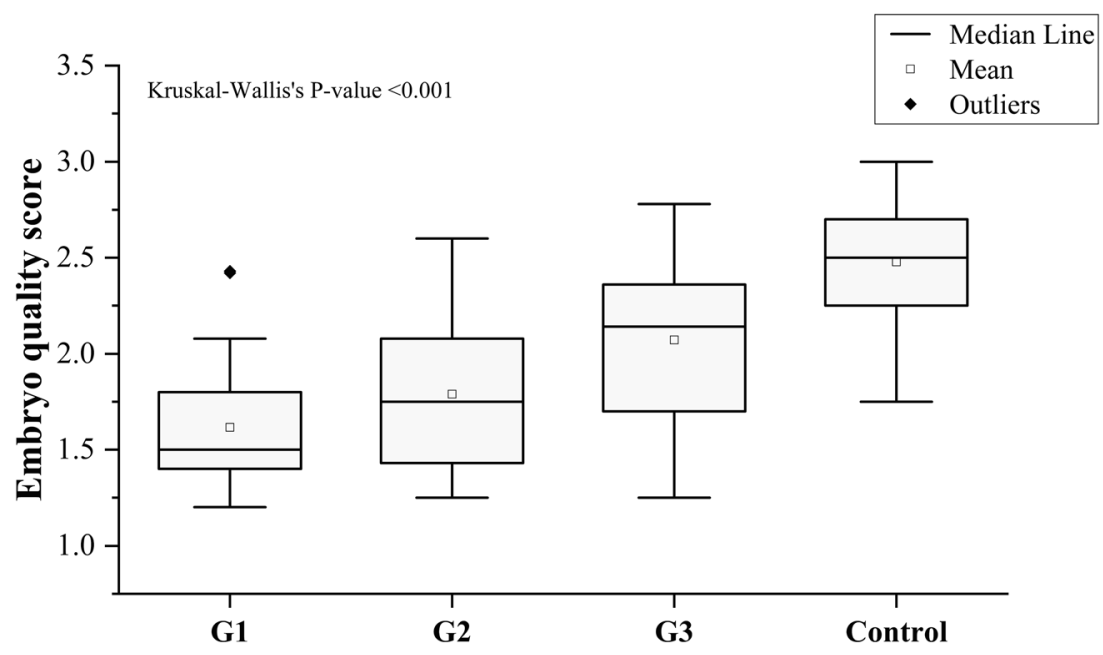

We think that the criteria used in the current study for sample selection and sample grouping influenced the results obtained. We excluded many environmental factors that are known to affect sperm motility, such as smoking, varicocele, alcoholism, and men older than 40 years old. These factors have already been shown to affect sperm motility, and thus excluding them increases the probability of identifying the genetic etiology [39, 40]. Most of the previous studies, the patients' grouping was done by including all sperm abnormalities together as one group, while in our study asthenozoospermic patients were divided into different categories, where the reduced sperm motility varied between 0 and $35 \%$. Samples with sperm motility between 36 and $40 \%$ were excluded to stay far from the borderline of the normal percentage (40\%) of total sperm motility recommended by the WHO [41]. We also relied on the percentage of total sperm motility rather than on the type of sperm motility, because, according to $\mathrm{WHO}$, progressive motility (type A and type B) should be greater than $32 \%$. So, as our samples were evaluated by different embryologists, it could be more reliable to depend on total sperm motility where it is easier to distinguish between motile and immotile sperm, rather than determining the specific type of sperm; this also decreases the number of individual errors among technicians.

Recent studies have provided evidence supporting the paternal transmission of mtDNA. Luo and co-workers presented a strong evidence for a bi-parental mtDNA inheritance, following the pattern of mitochondrial disease inheritance in three separate multi-generation families; they showed evidence of parental mtDNA transmission from father to offspring [15]. Ecker et al. found that sons who were born by ICSI shared the same SNPs in mitochondrial genes (COXI, $N D 1, N D 4$, and ND5) with their fathers; also, they found that the degree of similarity reached in some cases up to $99 \%$ of the paternal mtDNA [17]. Another study found that mtDNA myopathy can be transmitted from the father to the son by ICSI, and that spermatozoa mtDNA mutations were maintained in the embryo [42]. However, it is expected that the effect of paternal mtDNA variants will be diluted since the unfertilized oocyte contains around 150,000 copies of mtDNA, compared to sperm which contain around only 100 copies [43]. It remains to be determined how common paternal mtDNA inheritance is especially in ICSI settings, and the phenotypic consequences it may cause.

\section{Conclusions}

We found that the frequencies of total mitochondrial variants in $N D 1, N D 2, N D 5$, and $N D 6$ genes were negatively correlated with the percentages of sperm motility and ICSI outcomes. We also identified three variants, $13708 \mathrm{G}>\mathrm{A}, 4216 \mathrm{~T}>\mathrm{C}$, and $12506 \mathrm{~T}>\mathrm{A}$, to be negatively correlated with sperm motility and ICSI outcomes. Future studies are needed to determine the functional consequences of the identified variants, and to understand the mechanism of how the fertilization rate is affected by sperm mtDNA, specifically in the early stage of embryo development. Despite the recent studies to identify the genetic basis of male infertility in Jordan [44-46], its cause remains unknown in a large number of cases. Highthroughput genomic studies to identify the genetic etiology for infertility in Jordan should therefore be undertaken.

Acknowledgments We would like to thank all embryologists at the IVF unit in the Jordanian Royal Medical Services for their efforts in collecting and evaluating the semen samples and for providing the data about the patients. We are also grateful to all technicians and embryologists in the Department of Reproductive Medicine at Saarland University for providing technical help for this study.

Authors' Contributions MAS: conducted the experiments and generated the manuscript. MEH: designed the study and contributed to data interpretation and analysis. ES: methodology. OB: manuscript editing. MMA: statistical analysis. MYJ: methodology. MASH: bioinformatics analysis. BN: clinical supervision. HA: methodology and supervision. All authors approved the final version and the submission of this article. 
Funding Open Access funding enabled and organized by Projekt DEAL. This project was funded by a grant from the graduate school at Saarland University $(11 / 2018)$.

Data Availability Data are available upon request from the corresponding author.

\section{Compliance with Ethical Standards}

Competing Interests The authors declare that they have no conflict of interest.

Ethical Approval and Consent to Participation The study was approved by the Jordanian Royal Medical Services- Human Research Ethics Committee on 30/7/2018 with the project identification code (TF3/1/ Ethics Committee/9126).

\section{Consent for Publication Not applicable.}

Abbreviations ICSI, Intracytoplasmic sperm injection; MtDNA, Mitochondrial DNA; ROS, Reactive oxygen species; OxPhos, Oxidative phosphorylation; SNP, Single nucleotide polymorphism; IVF, In vitro fertilization; WHO, World Health Organization; HEPES, 4-(2-Hydroxyethyl)-1-piperazineethanesulfonic acid; PCR, Polymerase chain reaction; NCBI, National Centre of Biotechnology Information; ACMG, American College of Medical Genetics and Genomics; SQSTM1, Sequestosome 1; MDPs, Mitochondrial-derived peptides; UPR, Unfolded protein response; PR, Progressive motility; NP, Nonprogressive motility

Open Access This article is licensed under a Creative Commons Attribution 4.0 International License, which permits use, sharing, adaptation, distribution and reproduction in any medium or format, as long as you give appropriate credit to the original author(s) and the source, provide a link to the Creative Commons licence, and indicate if changes were made. The images or other third party material in this article are included in the article's Creative Commons licence, unless indicated otherwise in a credit line to the material. If material is not included in the article's Creative Commons licence and your intended use is not permitted by statutory regulation or exceeds the permitted use, you will need to obtain permission directly from the copyright holder. To view a copy of this licence, visit http://creativecommons.org/licenses/by/4.0/.

\section{References}

1. Cohen P. Comparing the utility of mitochondrial and nuclear DNA to adjust for genetic ancestry in association studies. Cells. 2019;8(4):306. https://doi.org/10.3390/cells8040306.

2. Frazier AE, Thorburn DR, Compton AG. Mitochondrial energy generation disorders: genes, mechanisms, and clues to pathology. J Biol Chem. 2019;294(14):5386-95. https://doi.org/10.1074/jbc. R117.809194.

3. Piomboni P, Focarelli R, Stendardi A, Ferramosca A, Zara V. The role of mitochondria in energy production for human sperm motility. Int J Androl. 2012;35(2):109-24. https://doi.org/10.1111/j. 1365-2605.2011.01218.x.

4. Stewart JB, Chinnery PF. The dynamics of mitochondrial DNA heteroplasmy: implications for human health and disease. Nat Rev Genet. 2015;16(9):530-42. https://doi.org/10.1038/nrg3966.

5. O'Connell M, McClure N, Lewis SEM. A comparison of mitochondrial and nuclear DNA status in testicular sperm from fertile men and those with obstructive azoospermia. Hum Reprod. 2002;17(6):1571-7. https://doi.org/10.1093/humrep/17.6.1571.

6. Moscatelli N, et al. Comparative proteomic analysis of proteins involved in bioenergetics pathways associated with human sperm motility. Int J Mol Sci. 2019;20:12. https://doi.org/10.3390/ ijms20123000.

7. Spiropoulos J. Can mitochondrial DNA mutations cause sperm dysfunction? Mol Hum Reprod. 2002;8(8):719-21. https://doi. org/10.1093/molehr/8.8.719.

8. Wai T, Ao A, Zhang X, Cyr D, Dufort D, Shoubridge EA. The role of mitochondrial DNA copy number in mammalian fertility 1 . Biol Reprod. 2010;83(1):52-62. https://doi.org/10.1095/biolreprod.109. 080887.

9. Aitken RJ, Drevet JR. The importance of oxidative stress in determining the functionality of mammalian spermatozoa: A two-edged sword. Antioxidants. 2020;9:2. https://doi.org/10.3390/ antiox 9020111.

10. Hammadeh ME, Filippos AA, Hamad MF. Reactive oxygen species and antioxidant in seminal plasma and their impact on male fertility. Int J Fertil Steril. 2009;3(3):87-110.

11. Ochsendorf FR. Infections in the male genital tract and reactive oxygen species. Hum Reprod Update. 1999;5(5):399-420. https:// doi.org/10.1093/humupd/5.5.399.

12. Koppers AJ, De Iuliis GN, Finnie JM, McLaughlin EA, Aitken RJ. Significance of mitochondrial reactive oxygen species in the generation of oxidative stress in spermatozoa. J Clin Endocrinol Metab. 2008;93(8):3199-207. https://doi.org/10.1210/jc.2007-2616.

13. Ko AEY, Sabanegh ES Jr, Agarwal. Male infertility testing: reactive oxygen species and antioxidant capacity. Fertil Steril. 2014;102(6):1518-27.

14. Micheli L, Cerretani D, Collodel G, Menchiari A, Moltoni L, Fiaschi AI, et al. Evaluation of enzymatic and non-enzymatic antioxidants in seminal plasma of men with genitourinary infections, varicocele and idiopathic infertility. Andrology. 2016;4(3):456-64. https://doi.org/10.1111/andr.12181.

15. Luo S, Valencia CA, Zhang J, Lee NC, Slone J, Gui B, et al. Biparental inheritance of mitochondrial DNA in humans. Proc Natl Acad Sci U S A. 2018;115(51):13039-44. https://doi.org/10. 1073/pnas. 1810946115.

16. Annis S, Fleischmann Z, Khrapko M, Franco M, Wasko K, Woods $\mathrm{D}$, et al. Quasi-Mendelian paternal inheritance of mitochondrial DNA: a notorious artifact, or anticipated behavior? Proc Natl Acad Sci U S A. 2019;116(30):14797-8. https://doi.org/10.1073/ pnas. 1821436116.

17. Eker C, Goksever H, Karamustafaoglu B, Gunel T. European Journal of Obstetrics \& Gynecology and Reproductive Biology Investigation of human paternal mitochondrial DNA transmission in ART babies whose fathers with male infertility. Eur J Obstet Gynecol. 2019;236:183-92. https://doi.org/10.1016/j.ejogrb.2019. 02.011 .

18. Holyoake AJ, McHugh P, Wu M, O'Carroll S, Benny P, Sin IL, et al. High incidence of single nucleotide substitutions in the mitochondrial genome is associated with poor semen parameters in men. Int J Androl. 2001;24(3):175-82. https://doi.org/10.1046/j.13652605.2001.00292.x.

19. Ji J, et al. Mitochondrial DNA sequencing and large-scale genotyping identifies MT-ND4 gene mutation m.11696G\&gt;A associated with idiopathic oligoasthenospermia. Oncotarget. 2017;8(32): 52975-82. https://doi.org/10.18632/oncotarget.17675.

20. Wu H, Whitcomb BW, Huffman A, Brandon N, Labrie S, Tougias E, et al. Associations of sperm mitochondrial DNA copy number and deletion rate with fertilization and embryo development in a clinical setting. Hum Reprod. 2019;34(1):163-70. https://doi.org/ 10.1093/humrep/dey330.

21. Vanniarajan A, Govindaraj P, Carlus SJ, Aruna M, Aruna P, Kumar A, et al. Mitochondrial DNA variations associated with recurrent 
pregnancy loss among Indian women. Mitochondrion. 2011;11(3): 450-6. https://doi.org/10.1016/j.mito.2011.01.002.

22. Weitzman VN, Schnee-Riesz J, Benadiva C, Nulsen J, Siano L, Maier D. Predictive value of embryo grading for embryos with known outcomes. Fertil Steril. 2010;93(2):658-62. https://doi.org/ 10.1016/j.fertnstert.2009.02.032.

23. Griffiths TA, Murdoch AP, Herbert M. Embryonic development in vitro is compromised by the ICSI procedure. Hum Reprod. 2000;15(7):1592-6. https://doi.org/10.1093/humrep/15.7.1592.

24. Scott L. The morphology of human pronuclear embryos is positively related to blastocyst development and implantation. Hum Reprod. 2000;15(11):2394-403. https://doi.org/10.1093/humrep/ 15.11.2394.

25. Nasr-Esfahani MH, Razavi S, Mardani M, Shirazi R, Javanmardi S. Effects of failed oocyte activation and sperm protamine deficiency on fertilization post-ICSI. Reprod BioMed Online. 2007;14(4): 422-9. https://doi.org/10.1016/S1472-6483(10)60888-7.

26. Crispim D, Canani LH, Gross JL, Tschiedel B, Souto KEP, Roisenberg I. The European-specific mitochondrial cluster J/T could confer an increased risk of insulin-resistance and type 2 diabetes: an analysis of the $\mathrm{m} .4216 \mathrm{~T}>\mathrm{C}$ and $\mathrm{m} .4917 \mathrm{~A}>\mathrm{G}$ variants. Ann Hum Genet. 2006;70(4):488-95. https://doi.org/10.1111/j. 1469-1809.2005.00249.x.

27. Gomez R, O'Keeffe T, Chang LY, Huebinger RM, Minei JP, Barber RC. Association of mitochondrial allele 4216C with increased risk for complicated sepsis and death after traumatic injury. J Trauma - Inj Infect Crit Care. 2009;66(3):850-7. https://doi.org/ 10.1097/TA.0b013e3181991ac8.

28. Yu X, Koczan D, Sulonen AM, Akkad DA, Kroner A, Comabella $\mathrm{M}$, et al. mtDNA nt13708A variant increases the risk of multiple sclerosis. PLoS One. 2008;3(2):1-7. https://doi.org/10.1371/ journal.pone.0001530.

29. Brown MD, Shoffner JM, Kim YL, Jun AS, Graham BH, Cabell MF, et al. Mitochondrial DNA sequence analysis of four Alzheimer's and Parkinson's disease patients. Am J Med Genet. 1996;61(3):283-9. https://doi.org/10.1002/(SICI)10968628(19960122)61:3<283::AID-AJMG15>3.0.CO;2-P.

30. Maruszak A, Canter JA, Styczyńska M, Zekanowski C, Barcikowska M. Mitochondrial haplogroup H and Alzheimer's disease-is there a connection? Neurobiol Aging. 2009;30(11): 1749-55. https://doi.org/10.1016/j.neurobiolaging.2008.01.004.

31. Selvi Rani D, Vanniarajan A, Gupta NJ, Chakravarty B, Singh L, Thangaraj K. A novel missense mutation C11994T in the mitochondrial ND4 gene as a cause of low sperm motility in the Indian subcontinent. Fertil Steril. 2006;86(6):1783-5. https://doi. org/10.1016/j.fertnstert.2006.04.044.

32. Mimaki M, Wang X, McKenzie M, Thorburn DR, Ryan MT. Understanding mitochondrial complex I assembly in health and disease. Biochim Biophys Acta Bioenerg. 2012;1817(6):851-62. https://doi.org/10.1016/j.bbabio.2011.08.010.

33. Yano T, Magnitsky S, Ohnishi T. Characterization of the complex I-associated ubisemiquinone species: toward the understanding of their functional roles in the electron/proton transfer reaction. Biochim Biophys Acta Bioenerg. 2000;1459(2-3):299-304. https://doi.org/10.1016/S0005-2728(00)00164-X.

34. Kumar R, Venkatesh S, Kumar M, Tanwar M, Shasmsi MB, Kumar R, et al. Oxidative stress and sperm mitochondrial DNA mutation in idiopathic oligoasthenozoospermic men. Indian $\mathrm{J}$ Biochem Biophys. 2009;46(2):172-7.

35. Mao GH, Huang XH, Geng XJ, Li Q, Zhang Y, Dou Q. Correlation between sperm mitochondrial ND5 and ND6 gene variations and total fertilisation failure. Arch Med Sci. 2020;16(2):692-8. https:// doi.org/10.5114/aoms.2020.94658.

36. Pereira L, Gonçalves J, Franco-Duarte R, Silva J, Rocha T, Arnold $\mathrm{C}$, et al. No evidence for an mtDNA role in sperm motility: data from complete sequencing of asthenozoospermic males. Mol Biol Evol. 2007;24(3):868-74. https://doi.org/10.1093/molbev/ msm004.

37. C. Herrnstadt et al., "2002 Herrnstadt Sequences for the Major African, Asian, and European Haplogroups.pdf," pp. 1152-1171, 2002.

38. Pereira L, Goncalves J, Bandelt HJ. Mutation C11994T in the mitochondrial ND4 gene is not a cause of low sperm motility in Portugal. Fertil Steril. 2008;89(3):738-41. https://doi.org/10.1016/ j.fertnstert.2007.03.048.

39. Tissera AD, Bello R, Beltramone F, Estofan G, Molina RI. Impact of age , clinical conditions, and lifestyle on routine semen parameters and sperm kinematics. 2018;110:1. https://doi.org/10.1016/j. fertnstert.2018.03.016.

40. Chhabra T, Dalal S, Prakash S, Nara N, Bhatia C, Beniwal JP. Effect of varicocelectomy on seminogram in patients with clinical varicocele. 2018;5(5):1831-7.

41. WHO, WHO laboratory manual for the examination and processing of human semen. 2010

42. Lestienne P. Oligoasthenospermia associated with multiple mitochondrial DNA rearrangements. Mol Hum Reprod. 1997;3(9):8114. https://doi.org/10.1093/molehr/3.9.811.

43. Chinnery PF, Hudson G. Mitochondrial genetics. Br Med Bull. 2013;106(1):135-59. https://doi.org/10.1093/bmb/ldt017.

44. Batiha O, Al-Ghazo MA, Elbetieha AM, Jaradat SA. Screening for deletions in the AZF region of Y chromosome in infertile Jordanian males. J Appl Biol Sci. 2012;6:2.

45. Al Zoubi MS, et al. 4,977-bp human mitochondrial DNA deletion is associated with asthenozoospermic infertility in Jordan: Andrologia; 2020. https://doi.org/10.1111/and.13379.

46. Batiha $\mathrm{O}$, et al. Molecular analysis of $\mathrm{CAG}$ repeat length of the androgen receptor gene and Y chromosome microdeletions among Jordanian azoospermic infertile males. Feb.: Andrologia; 2018. https://doi.org/10.1111/and.12979.

Publisher's Note Springer Nature remains neutral with regard to jurisdictional claims in published maps and institutional affiliations. 